\title{
WestVirginiaUniversity
}

THE RESEARCH REPOSITORY @ WVU

Faculty \& Staff Scholarship

Fall $11-26-2020$

\section{The Fold Illusion: The Origins and Implications of Ogives on Silicic Lavas}

\author{
Graham DM Andrews \\ West Virginia University, graham.andrews@mail.wvu.edu \\ Stuart Kenderes \\ University of Missouri \\ Alan Whittington \\ University of Texas at San Antonio \\ Shelby L. Isom \\ West Virginia University \\ Sarah Brown \\ WVGES
}

See next page for additional authors

Follow this and additional works at: https://researchrepository.wvu.edu/faculty_publications

Part of the Geology Commons, Tectonics and Structure Commons, and the Volcanology Commons

\section{Digital Commons Citation}

Andrews, Graham DM; Kenderes, Stuart; Whittington, Alan; Isom, Shelby L.; Brown, Sarah; Pettus, Holly Danielle; Cole, Brenna; and Gokey, Kailee, "The Fold Illusion: The Origins and Implications of Ogives on Silicic Lavas" (2020). Faculty \& Staff Scholarship. 2950.

https://researchrepository.wvu.edu/faculty_publications/2950

This Article is brought to you for free and open access by The Research Repository @ WVU. It has been accepted for inclusion in Faculty \& Staff Scholarship by an authorized administrator of The Research Repository @ WVU. For more information, please contact beau.smith@mail.wvu.edu. 


\section{Authors}

Graham DM Andrews, Stuart Kenderes, Alan Whittington, Shelby L. Isom, Sarah Brown, Holly Danielle Pettus, Brenna Cole, and Kailee Gokey 


\title{
The fold illusion: The origins and implications of ogives on silicic lavas
}

\author{
Graham D.M. Andrews ${ }^{\mathrm{a}, *}$, Stuart M. Kenderes ${ }^{\mathrm{b}}$, Alan G. Whittington ${ }^{\mathrm{c}}$, Shelby L. Isom ${ }^{\mathrm{a}}$, \\ Sarah R. Brown ${ }^{\mathrm{a}, \mathrm{d}}$, Holly D. Pettus ${ }^{\mathrm{a}}$, Brenna G. Cole ${ }^{\mathrm{a}}$, Kailee J. Gokey ${ }^{\mathrm{a}}$ \\ a West Virginia University, United States of America \\ ${ }^{\mathrm{b}}$ University of Missouri, United States of America \\ ${ }^{\mathrm{c}}$ University of Texas at San Antonio, United States of America \\ ${ }^{d}$ West Virginia Geological and Economic Survey, United States of America
}

\section{A R T I C L E I N F O}

\section{Article history:}

Received 17 January 2020

Received in revised form 11 May 2020

Accepted 13 October 2020

Available online 9 November 2020

Editor: H. Handley

\section{Keywords:}

silicic lava

ogives

tensile fractures

viscometry

obsidian

\begin{abstract}
A B S T R A C T
Folds on the surfaces of mafic lavas are among the most readily recognized geological structures and are used as first-order criteria for identifying ancient lavas on Earth and other planetary bodies. However, the presence of surface-folds on the surface of silicic lavas is contested in this study and we challenge the widely accepted interpretation that silicic lava surfaces contain folds using examples from the western United States and Sardinia, Italy. We interpret the ridges and troughs on their upper surfaces, typically referred to as 'ogives' or 'pressure ridges', as fracture-bound structures rather than folds. We report on the absence of large-scale, buckle-style folds and note instead the ubiquitous presence of multiple generations and scales of tensile fractures comparable to crevasses in glaciers and formed in ways similar to already recognized crease structures. We report viscosity data and results of stress analyses that preclude folding (ductile deformation in compression) of the upper surface of silicic lavas at timescales of emplacement (weeks to months). Therefore, analysis of fold geometry (wavelength, amplitude, etc.) is erroneous, and instead the signal produced reflects the strength and thickness of the brittle upper surface stretching over a ductile interior. The presence of ogives on the surfaces of lavas on other planetary bodies may help to elucidate their rheological properties and crustal thicknesses, but relating to their tensile strength, not viscosity.
\end{abstract}

(C) 2020 The Author(s). Published by Elsevier B.V. This is an open access article under the CC BY-NC-ND license (http://creativecommons.org/licenses/by-nc-nd/4.0/).

\section{Introduction}

'Ogives', sometimes referred to as 'pressure ridges', are parabolic laterally discontinuous ridges and troughs occurring on the upper surfaces of many lavas varying in composition from basalt to rhyolite, and they are characteristic of silicic lavas (Fig. 1). The patterns produced by ogives are remarkably regular and predictable (Fink, 1980a), suggesting that their sizes and spacings relate to the mechanical nature of the lava and the deformation processes operating during emplacement. Several studies have applied aspects of fold theory to ogives in attempts to constrain silicic lava viscosity during flow (e.g., Fink, 1980a; Gregg et al., 1998; Maeno and Taniguchi, 2006; Farrell et al., 2018; Deardorff et al., 2019). Studies based on fold theory attribute the frequencies and amplitudes to viscosity contrasts between adjacent layers (e.g., Fink, 1980a; Gregg et al., 1998), whereby estimating the viscosity of one layer constrains that of the other layers.

\footnotetext{
* Corresponding author.

E-mail address: graham.andrews@mail.wvu.edu (G.D.M. Andrews).
}

Herein we challenge the common interpretation that ogives on silicic lavas are folds (cf. Fink, 1980a; Gregg et al., 1998; Farrell et al., 2018; Fink, 1983; Harris et al., 2017; Bullock et al., 2018). The fold interpretation is supported by few first-order field observations (e.g., Fink, 1980a, 1983; Bullock et al., 2018) compared to the number of related analog and numerical modeling studies (Fink, 1980a; Gregg et al., 1998; Farrell et al., 2018; Deardorff et al., 2019; Fink, 1980b; Baum et al., 1989; Fink and Griffiths, 1992; Pappalardo and Greeley, 1995; Fink and Griffiths, 1998; Lescinsky and Merle, 2005; Lescinsky et al., 2007; Leggett et al., 2020). Through analysis of new field observations, viscometry experiments, and stress modeling, we deduce that ogives are brittletensile features that record brittle failure and stretching of the upper surface as the lava advances and spreads.

Re-evaluating the origins of ogives is important for two reasons: (1) folding of the upper surface implies that ductile and layer-parallel compression are the dominant states of rheology and stress (Fink, 1980a; Farrell et al., 2018), respectively; this has implications for the thermal structures of silicic lavas and the timescales of their emplacement. (2) Fold theory has been applied 
widely to ogives to constrain the rheologies and compositions of inaccessible lavas, for example, submarine (Ikegami et al., 2018) and extraterrestrial lavas (Fink, 1980a,b; Fink et al., 1983; Theilig and Greeley, 1986; Byrnes et al., 1997; Warner and Gregg, 2003; Barr and Preuss, 2010), and has received renewed interest for terrestrial lavas due to the increasing availability of high-resolution digital terrain models (MacKay et al., 1998; Stevens, 2002; Cashman et al., 2013; Hunt et al., 2019). Understanding of how silicic lavas are emplaced is changed fundamentally if ogives are not folds, and the application of fold theory is not valid.

\section{Background}

Ogives are described in ice-glaciers (Hambrey and Lawson, 2000), salt-glaciers ('namakiers' Talbot and Pohjola, 2009), rockglaciers (Kääb and Weber, 2004), lavas (e.g., Figs. 1 \& 2A), and cryolavas (Barr and Preuss, 2010). We use the term 'ogive' in the same non-genetic sense that it was originally used in the 1840 s (Campbell and Hutchison, 1978) for $10 \mathrm{~m}$ - to $\mathrm{m}$-scale, parabolic or hyperbolic ridges and troughs on the upper surfaces of some alpine ice-glaciers. Ogives do not include recumbent folds at the margins or in the interiors (e.g., Fig. 2B; Bullock et al., 2018; Talbot and Pohjola, 2009; Smith and Houston, 1994), nor the abundant and topologically diverse $\mathrm{cm}$ - to $\mathrm{m}$-scale folds within lavas (e.g., Fig. 2C; Bullock et al., 2018; Christiansen and Lipman, 1966; Castro and Cashman, 1999). We use 'ogive' as it describes a shape, unlike 'pressure ridge' that has different genetic meanings in glaciology and geomorphology, and is used inconsistently in physical volcanology (e.g., Whitehead and Stephenson, 1998).

\subsection{Structures on silicic lavas}

Silicic lavas (dacites and rhyolites) are less common and voluminous on Earth than mafic lavas but are geographically widespread and preserved throughout the geological record. Although strongly-channelized trachytic (MacKay et al., 1998) and dacitic (Harris et al., 2002) lavas, and a single small, largely submarine rhyolite lava (Maeno and Taniguchi, 2006) have been observed flowing, the only modern observation of the emplacement of an extensive, rhyolitic lava is from the 2011-13 eruption of Puyehue - Cordón Caulle, Chile (Tuffen et al., 2013). Most Holocene silicic lavas are characterized by ogives on their upper surfaces (e.g., Fig. 1) and these were observed to form at both Showa Iwo-jima, Japan (1934-35 Maeno and Taniguchi, 2006) and Cordón Caulle (Farquharson et al., 2015). Ancient lavas, however, have variable preservation of ogives on exposed surfaces that have usually been eroded or part-buried or both (e.g., Cioni and Funedda, 2005).

\subsubsection{Lithofacies}

The upper surfaces of silicic lavas are composed of three structural features: ogives, crease structures, and areas of autobreccia between them. These features are superimposed upon three lithofacies (Fink, 1983; Manley and Fink, 1987; Fink et al., 1992) that are defined by their vesicularity: avesicular, flow-banded obsidian; finely vesicular pumice (FVP); and coarsely vesicular pumice (CVP). They form a general lithostratigraphy of FVP at the upper surface over a layer of black obsidian that overlies a layer of CVP (Fink, 1983; Manley and Fink, 1987). A fourth, lithoidal rhyolite lithofacies (Manley and Fink, 1987) is largely absent from the upper surface. FVP is light grey and characterized by abundant, small ( $\leq 0.5 \mathrm{~mm}$-diameter), often slightly stretched, vesicles, porosity 30 $40 \%$, and bulk density $\geq 1 \mathrm{~g} / \mathrm{cm}^{3}$. CVP is typically dark grey-green to black and characterized by large $(0.1-1 \mathrm{~cm}$-diameter) interconnected vesicles, porosity $20-80 \%$, and bulk density $\leq 1 \mathrm{~g} / \mathrm{cm}^{3}$. FVP and CVP are interpreted to form from hydrous obsidian by different vesiculation processes (Manley and Fink, 1987): FVP by exsolution
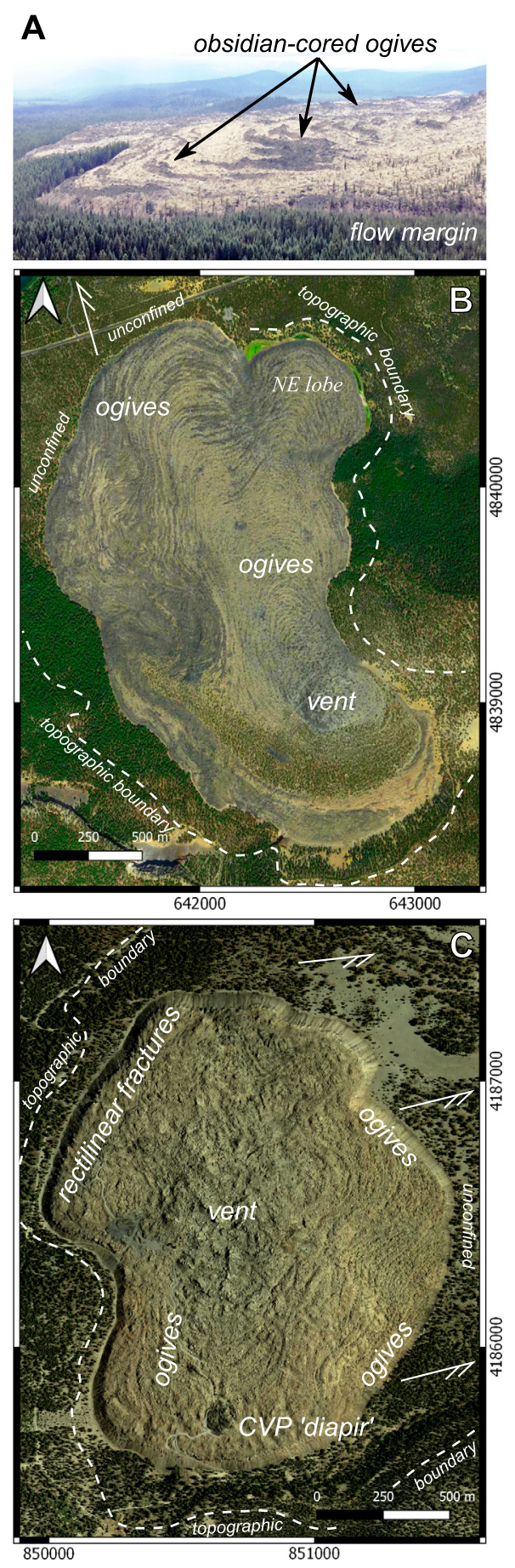

Fig. 1. (A) Oblique view of the southeastern margin of Little Glass Mountain, Medicine Lake volcano, California, showing semi-continuous ogive structures formed of obsidian and coarsely vesicular pumice (CVP), parallel to the margin. (B) Planview image of the Big Obsidian Flow coulée and underlying slope, Newberry caldera, Oregon. Half-arrows show the slope direction. (C) Plan-view of Obsidian Dome, California.

driven by equilibration with atmospheric pressure at the upper surface, and CVP by inflation due to a volatile overpressure from infiltrating magmatic gas.

\subsubsection{Ogives}

In plan-view the ogives are convex in the direction of flow in coulées (Fig. 1B; (Harris et al., 2017; Lescinsky and Merle, 2005)) or circumferential around equidimensional lavas (Fig. 1C). Ridge spacings on most silicic lavas range from $\geq 2-85 \mathrm{~m}$ (Fink, 

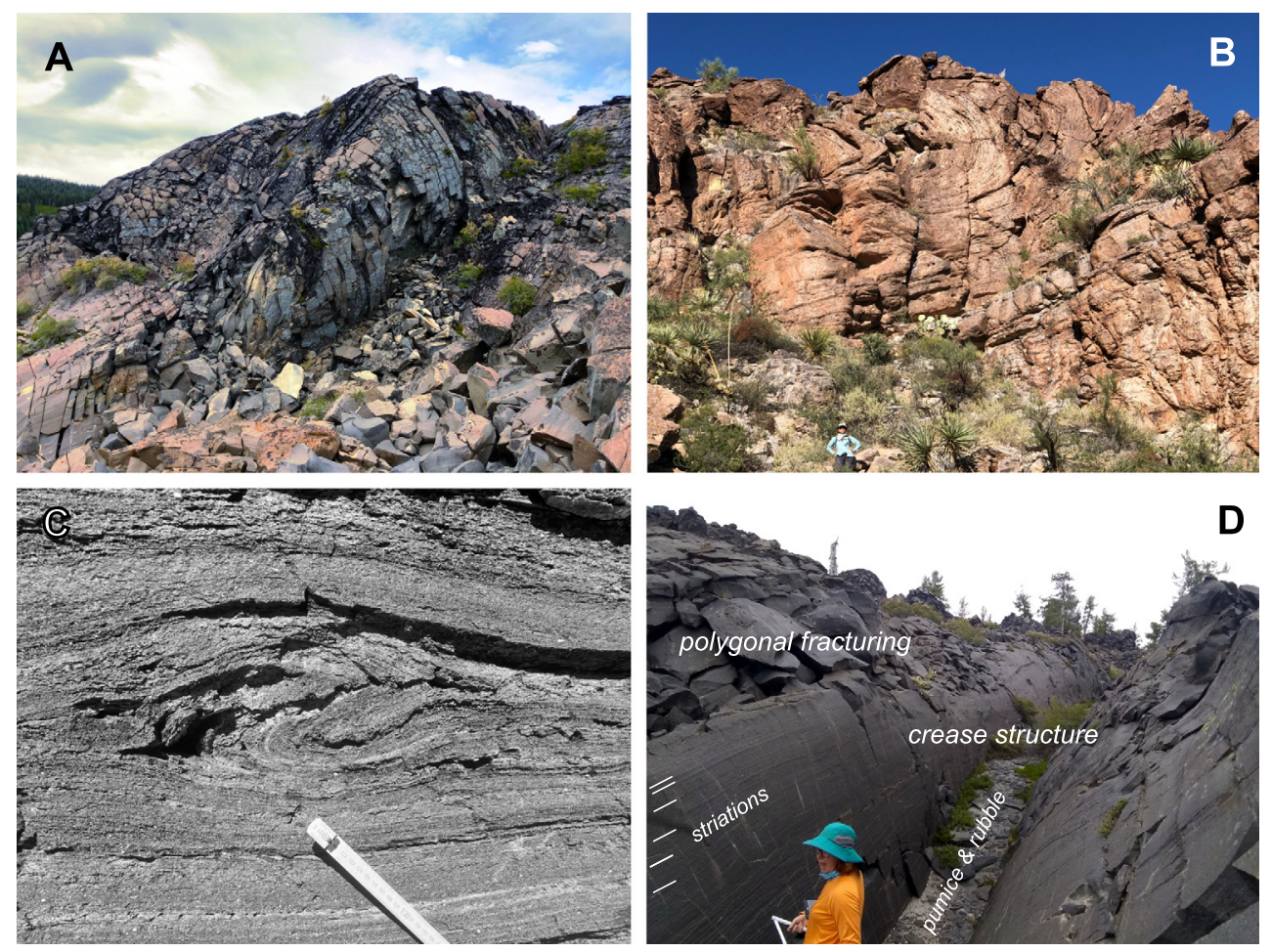

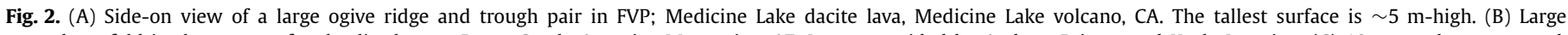

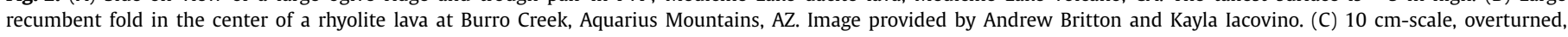
intrafolial fold pair in CVP; Big Glass Mountain, Medicine Lake volcano, CA. (D) Large crease structure in obsidian; Medicine Lake dacite.

1980a; Maeno and Taniguchi, 2006; Deardorff et al., 2019; Fink, 1983; Leggett et al., 2020), often decreasing towards the margins (e.g., Fig. 1C; Maeno and Taniguchi, 2006; Leggett et al., 2020). Ridge lengths have not been measured and recorded systematically; however, a review of published airphoto interpretations (Maeno and Taniguchi, 2006; Fink, 1983; Bullock et al., 2018; Farquharson et al., 2015) suggests that they range from $20-\leq 100 \mathrm{~m}$ in length (e.g., Fig. 1A). Ogive amplitudes range from $2-4 \mathrm{~m}$ on Showa Iwo-jima (Maeno and Taniguchi, 2006) and the Medicine Lake dacite, CA (Lescinsky et al., 2007), 2-6 m on Big Obsidian Flow and Rock Mesa, OR (Deardorff et al., 2019), and $\sim 5-15 \mathrm{~m}$ on Obsidian Dome and South Coulee, CA (Leggett et al., 2020), but do not vary systematically with distance from the vent. The importance of lava thickness or volume on ogive scale is uncertain; however, the voluminous $\left(24 \mathrm{~km}^{3}\right)$ Chao dacite, Chile, has ridge spacings of $\leq 200 \mathrm{~m}$ and amplitudes of $\sim 30 \mathrm{~m}$ (Fink, 1980a).

On closer inspection, the ogives are alternating, parallel ridges and troughs with steep, smooth, moderately to strongly curviplanar, marginal surfaces (Fig. 2A) and are typically cored by obsidian, CVP, or both (Fink, 1983). Ogive ridges and troughs are laterally discontinuous (Fig. 1A; Fink, 1983) and they plunge and terminate (e.g., Fig. 2A) in opposite directions at opposing ends (i.e. doublyplunge): they are periclinal. The ridges are typically broad, convexupwards features interpreted as upright, open - tight antiformal folds (e.g., Fink, 1980a; Maeno and Taniguchi, 2006; Fink, 1983; Lescinsky et al., 2007); however, they are very unlike the adjacent troughs that are strongly cuspate and are interpreted as upright, closed - isoclinal synforms. The ridges typically dip steeply towards the vent $\left(\sim 60^{\circ}-90^{\circ}\right.$ Maeno and Taniguchi, 2006; Leggett et al., 2020) and their axes are sub-parallel to the strike of the steep flow-banding foliation at the top of the lava (Maeno and Taniguchi, 2006; Fink, 1983; Christiansen and Lipman, 1966; Loney, 1968). This means that the ogives are neither cylindrical nor sinusoidal.

The ridges are variably fractured and brecciated in situ (Maeno and Taniguchi, 2006; Fink, 1983; Loney, 1968), such that the tops of some ridges are broader and less convex upwards than others, even along the length of a single ridge, and the troughs are partfilled with autobreccia (Fink, 1980a). Fractures are usually open voids but a minority are filled with welded breccia and tuffisite (Maeno and Taniguchi, 2006). The flattening of ridges and infilling of troughs lowers the relief of the upper surface (Lescinsky et al., 2007).

\subsubsection{Crease structures}

Ogives occur with, and are often cross-cut or truncated by, mto $10 \mathrm{~m}$-scale splaying fractures termed 'crease structures' (Fig. 2D) (Fink, 1983; Anderson and Fink, 1992). They can be radial about a central point, parallel and perpendicular to the margins, or form en échelon arrays. The fracture surfaces are smooth (Lescinsky et al., 2007), strongly curviplanar, usually symmetrical, and can be reconstructed back to a single, vertical, planar mode-I (tensile) fracture when pinning points on either side are matched (Fink, 1983) where the fracture propagated downwards. Most crease structures have splayed open to a maximum width of $\sim 5 \mathrm{~m}$ (Fink, 1983; Anderson and Fink, 1992), and rarely >30 m (Lescinsky et al., 2007; Anderson and Fink, 1992). Lengths have not been documented systematically but range from 20-50 m (Maeno and Taniguchi, 2006; Fink, 1983; Lescinsky et al., 2007; Anderson and Fink, 1992), within the range of ogive ridges and troughs. Some but not all crease structures are associated with masses of CVP that may have ascended as diapirs (e.g., Fig. 1C; Fink, 1983). Crease structures are interpreted as brittle-ductile tensile fractures, possibly amplified by cooling and contraction (Anderson and Fink, 1992), that experience viscous relaxation and spreading after the tensile stress is released. They are inferred to dilate parallel to the local flow direction (Anderson and Fink, 1992). Many crease structures exhibit 'striations' (Anderson and Fink, 1992) on their surfaces: parallel, sub-horizontal lines of vesicles and small cuspate fractures (Fig. 2D); they are interpreted to record incremental propagation of the crease structure's fracture tip, analogous to the propagation 
of cooling joints in mafic lavas to form columnar joints (Anderson and Fink, 1992).

\subsubsection{Autobreccia}

The majority of the surface area of a silicic lava is covered in an irregular and extremely rough (Deardorff et al., 2019; Lescinsky et al., 2007; Plaut et al., 2004), 1-10 m-thick carapace of autobreccia/talus, overwhelmingly composed of $\leq 1 \mathrm{~m}$-across (Anderson et al., 1998), angular blocks of FVP (Fink, 1983). In situ polygonal-fractures in ogive ridges and crease structure margins grade into discrete autobreccia blocks (Fig. 2D). Ogive ridges emerge as whalebacks from the expanse of autobreccia (Fig. 2A). Ogive troughs and crease structures are easily distinguished by the presence of autobreccia in troughs (Fig. 2A) and their absence from crease structures (Fig. 2D) (Anderson and Fink, 1992).

\subsection{The pāhoehoe rope - ogives analogy}

Many numerical studies of silicic lavas (Fink, 1980a; Gregg et al., 1998; Maeno and Taniguchi, 2006; Farrell et al., 2018; Deardorff et al., 2019; Lescinsky et al., 2007) assume that ogives are detachment folds which require a buckling component and a décollement (Butler et al., 2019), and that they can be considered as sinusoidal waves. The interpretation is encouraged by analogy with pāhoehoe lavas (Fink, 1980a; Gregg et al., 1998; Farrell et al., 2018; Fink and Fletcher, 1978) where $10 \mathrm{~cm}$ - to mm-scale folds ('ropes') are observed to form in the upper $\leq 50 \mathrm{~mm}$ of the quenching lobe (Fig. 3). Like ogives, pāhoehoe ropes have semi-regular spacings and heights, and are strongly convex in the direction of flow. However, the value of the analogy is weakened significantly by the facts that:

- The pāhoehoe ropes form during near-instantaneous quenching of the uppermost few millimeters to centimeters (Fig. 3) and only continue to form for as long as it is above the glass transition $\left(T_{g}\right)$. The underlying lava is flowing and spreading (i.e. extending) for a few seconds to minutes and can detach from the pāhoehoe crust, especially in highly vesicular spongy pāhoehoe (Harris et al., 2017).

- Pāhoehoe lobes form from small volume outbursts from the previous lobe where the lobe margin advances rapidly before suddenly stopping due to quenching. The trailing parts of the lobe collide with this suddenly emplaced barrier, and compress.

- Each pāhoehoe lobe $\left(\sim 1-\sim 100 \mathrm{~m}^{2}\right)$ produces its own ropes, and deformation is not shared across multiple lobes. The ropes are often more complexly twisted and braided together when observed in cross-section (Fig. 3) than they appear in planview.

- Pāhoehoe ropes are folds of a single continuous cooling surface, and although often convolute (Fig. 3), the surface can be traced over large distances relative to the wavelength of a single rope.

Fold frequency analysis (Fink, 1980a; Gregg et al., 1998; Deardorff et al., 2019; Lescinsky et al., 2007; Fink and Fletcher, 1978) applied to silicic lavas suggests that subtle 2nd- (Gregg et al., 1998), 3rd- (Pyle and Elliot, 2006) and 5th-order waveforms (Lescinsky et al., 2007), and possibly up to 8th-order waveforms (Deardorff et al., 2019), are superposed upon the upper surface and ogives (Gregg et al., 1998; Farrell et al., 2018) as type $0_{3}$ refolded folds (Grasemann et al., 2004). However, none of these higher-order waveforms have been identified and described independently in the field. It is from analyses like these that fold theory has been applied to constrain the effective viscosity of the lava (Fink, 1980a; Farrell et al., 2018; Fink and Fletcher, 1978), and

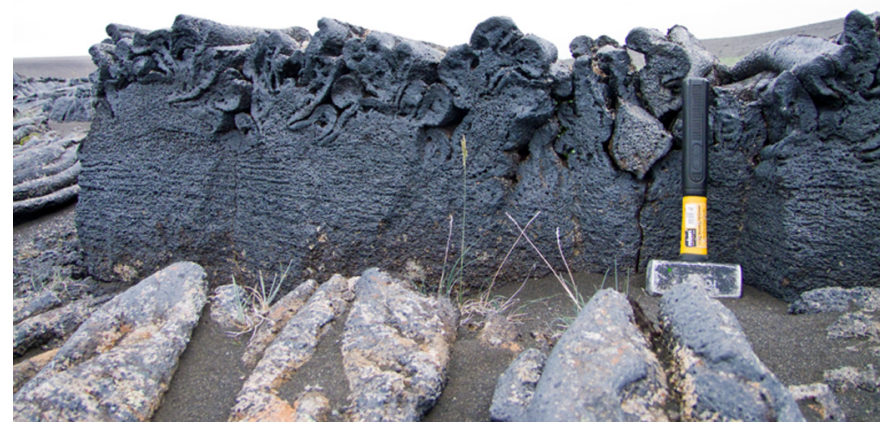

Fig. 3. Cross-sectional view the uppermost parts of a pāhoehoe lava from Skjaldbreiður, Iceland. Image provided by David McGarvie.

the bulk composition of the lava estimated (Fink, 1980a; Gregg et al., 1998; Hunt et al., 2019).

\section{Analysis}

Our analysis of the upper surfaces of silicic lavas is composed of three distinct parts: (1) structural observations and measurements in the field and from aerial imagery, (2) viscosity measurements and estimation of cooling rates, and (3) modeling of 2D stresses. Each analytical component is described in turn, and each independently contradicts existing models of silicic lava emplacement by ductile compression.

\subsection{Structural observations}

We completed reconnaissance surveying with a DJI Phantom 4 Advanced small unoccupied aerial system (sUAS) and new structural mapping at six Holocene silicic lavas in northern California and Oregon (Fig. S1A-C; see Fink and Anderson, 2017): Obsidian Dome and South Coulee (Long Valley caldera, CA); Little Glass Mountain (LGM), Big Glass Mountain (BGM), and Medicine Lake dacite (Medicine Lake caldera, CA); and Big Obsidian Flow (BOF) and Inter Lake (Newberry caldera, OR). These lavas were selected because they are easily accessible, excellently exposed, and are well documented. Accessible areas of the upper surfaces of each lava were explored and mapped to examine and describe the natures of the ogives and associated crease structures, and to constrain the geometry of the flow-banding. Emphasis was placed on identifying cross-sections through ogive ridges where they were truncated by crease structures or the lava margins. In addition, four Miocene comendite lavas on San Pietro Island, Sardinia, Italy (Fig. S1D; Cioni and Funedda, 2005) were examined in sea-cliffs, quarries, and road cuts, as well as in Google Earth imagery.

\subsubsection{Ogives in aerial imagery}

Examination of lidar and airphoto images (Fig. 1B, C) identified tens to hundreds of ogives at each lava. High-resolution (nominally $\leq 30 \mathrm{~cm} /$ pixel (horizontal)) digital terrain models (DTMs) and orthorectified color airphotos $(\leq 3 \mathrm{~cm} /$ pixel) produced from sUAS images by Structure-from-Motion (SfM) photogrammetry (e.g., Leggett et al., 2020; Tarolli, 2014) reveal new details about the shapes of ogive ridges and troughs, and how they interfere with each other, and surpass the level of detail available in $0.5-1 \mathrm{~m} /$ pixel resolution lidar images.

The Inter Lake lava (Fig. 4A; Robinson et al., 2015) has welldefined ogives that are parabolic about the medial axes or thalwegs. The lava erupted on the north-wall of the Newberry caldera and flowed south to abut the Central Pumice Cone. It then bifurcated and flowed east into East Lake and west into Paulina Lake 


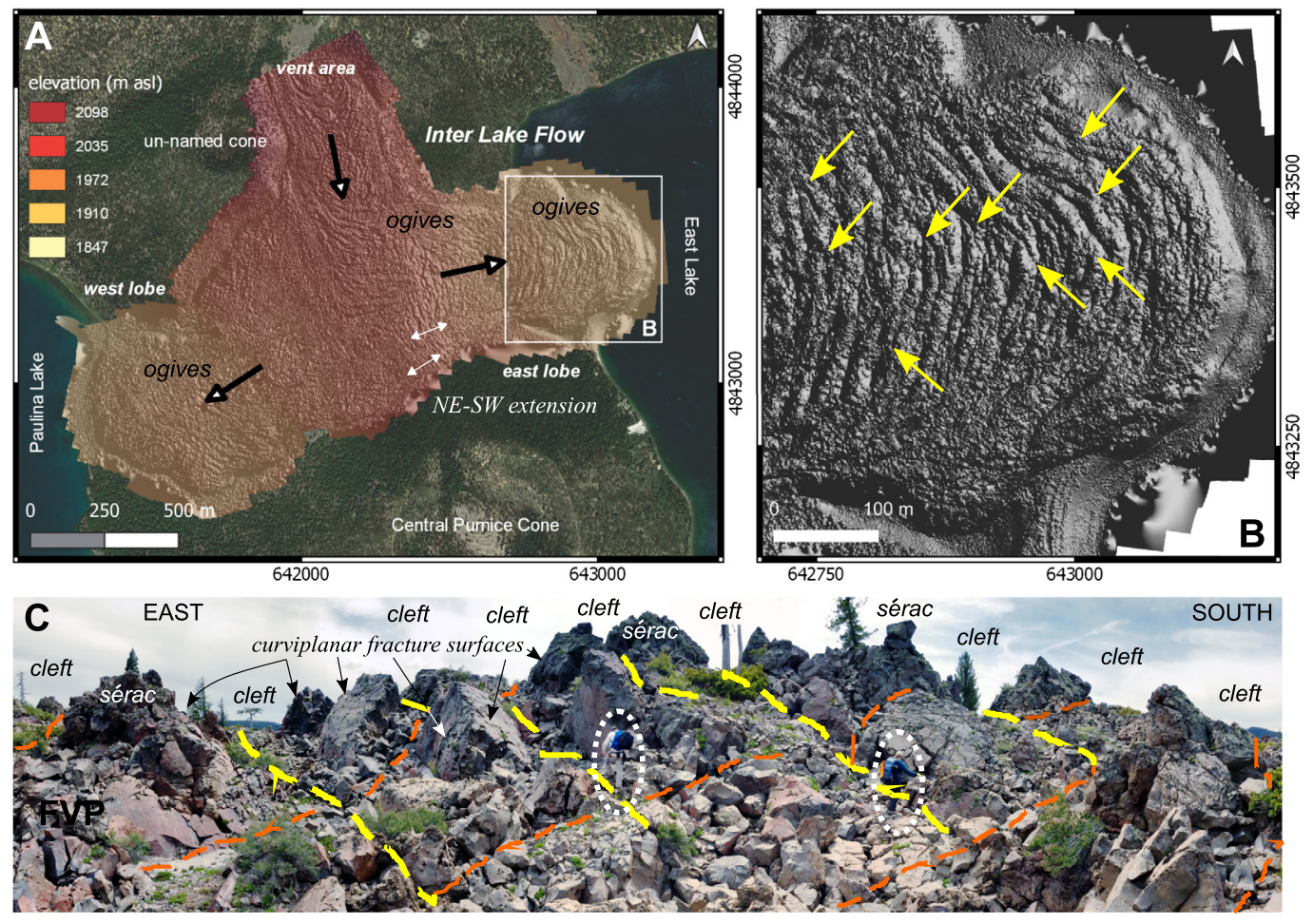

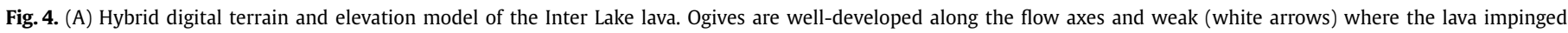

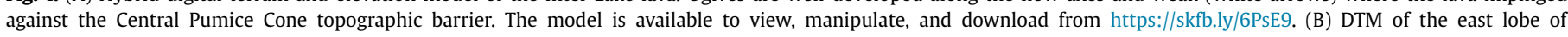

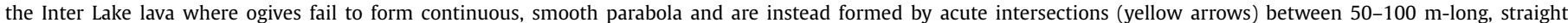

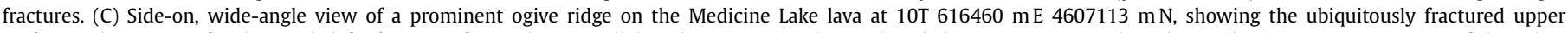

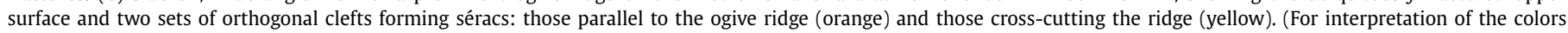
in the figure(s), the reader is referred to the web version of this article.)

along the thalwegs at the base of the Central Pumice Cone. There are no topographic barriers at the distal ends. Interestingly, where the lava abuts the Central Pumice Cone and bifurcates, the weaklydefined ogives are perpendicular to the margin and are parallel to the upflow thalweg and perpendicular to the downflow thalweg. The same relationship is observed at LGM (10T $609411 \mathrm{mE}$ $4602893 \mathrm{~m} \mathrm{~N}$ ) where the lava flowed NW and diverged around an older scoria cone to form two distinct lobes. Once again, weaklydefined ogives are perpendicular to the margin abutting the topographic obstruction.

The coulées on San Pietro Island show pronounced increases in ogive curvature downslope (e.g., 32S $433243 \mathrm{mE} 4333588 \mathrm{~m} \mathrm{~N}$ ). The ogives are almost straight (arc length $\left(L_{A}\right) /$ chord length $\left(L_{C}\right) \approx$ 1) and perpendicular to the coulées' medial axes at the highest exposures and become progressively more parabolic downslope $\left(L_{A} / L_{C} \geq 5\right)$ at runout distances of $\leq 1.5 \mathrm{~km}$ (Fig. 5). The same relationship is observed along the major flow-axes at BOF, Inter Lake, BGM, and LGM, although a comprehensive analysis remains to be completed.

The Inter Lake lava DTM (Fig. 4B) demonstrates well that the ogives are not laterally continuous and are instead short ( $\sim 40-100$ m-long), straight segments that cross-cut each other at high-oblique angles. This gives the appearance of laterally continuous, parabolic ridges and troughs, especially in lower resolution DTMs and two-dimensional representations. Individual troughs are observed to anastomose with the inflections in their trend occurring where adjacent ridges terminate. Similar relationships are observed on all the other Holocene lavas examined, and most clearly on the western lobe of the BGM (e.g., Models SM1 and SM2). There, en echelon crease structures with typical features (e.g., splaying, smooth curviplanar surfaces, striations, and a boulderfree base) have formed oblique to the ogives and cross-cut the ogive ridges (Model SM2). However, they do not obviously cross- cut and displace many of the ogive troughs and instead merge into and out of them at acute angles. The two longest crease structures terminate by bifurcating and merging with the adjacent troughs.

\subsubsection{Meso-scale structure of ogives}

CVP-cored ogives are the largest and often the most laterally continuous, but shorter and narrower FVP ogives are the most common. The overwhelming first impression of all ogives is that they are pervasively fractured at a range of scales ( $\mathrm{mm}$ to $\mathrm{m}$ ) and they have characteristically jagged profiles (Fig. 4C): they are not smooth or gently undulating. Ogive ridges are straight, 10-25 mlong sections that narrow from 5-20 m-wide at the base to acute fins at the crest. The upward-facing surfaces of ogive ridges are pervasively fractured by rectilinear and polygonal sets of $\mathrm{mm}$ to $5 \mathrm{~cm}$-wide, $\leq 50 \mathrm{~cm}$-deep tensile fractures, where each fracture tapers into the rock. The ridge margins are usually curviplanar surfaces of FVP or obsidian, but infrequently obsidian is covered by two distinctive veneers. These are polygonal-fractured and stretched red-brown oxidation surfaces (Fig. 6A) and convoluted oxidation surfaces where alternating flow-bands protrude in and out of the plane of the fracture (Fig. 6B), respectively. Some of the former can be traced down into welded and non-welded lapillituff filled fractures (Fig. 6C). Locally we find a third veneer type of polygonal-fractured and stretched, $\sim 1 \mathrm{~mm}$-thick, pink or lilac tuffisite on FVP or obsidian (Fig. 6D).

The ridges are disrupted by two orthogonal fracture sets: (1) 10-5 m-long and $\leq 5 \mathrm{~m}$-wide, cleft-shaped troughs parallel to the ridges, and (2) $\leq 2 \mathrm{~m}$-wide clefts that cross-cut the ridges and divide their ridgelines into 3-5 m-long segments (Fig. 4C). They are both sets of fractures because (1) they typically end at a tip-point below which the surrounding rock is undisturbed, (2) they tip-out at either end such that they deepest and widest in the middle, (3) their surfaces are sometimes ornamented with 


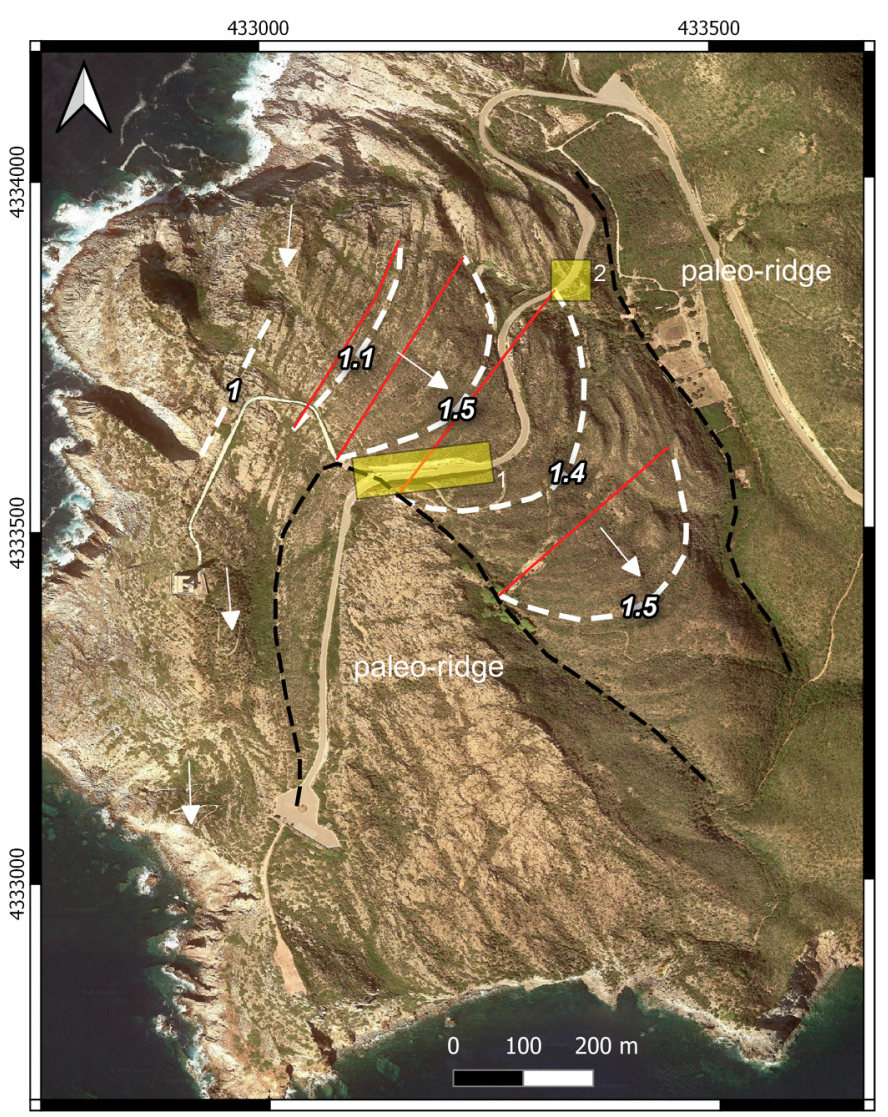

Fig. 5. Airphoto image of the Capo Sandalo lava (San Pietro Island) depicting the increasing curvature of ogives downslope to the southeast. The axes of five ridges are traced to show the progressive increase in the ratio of arc length (LA) to the corresponding chord length (LC). Yellow boxes highlight outcrops that provide crosssections through ogives.

plumous structures and hackly margins, and (4) the sides can be matched together with pinning points (e.g., Fig. 7A). The intersecting fractures produce square-based pinnacles identical in shape and proportion to séracs in glaciers (e.g., Colgan et al., 2016). Each ogive ridge is reminiscent of a shark's jaw: a gradual curve (the ogive) composed of discreet straight, barbed sections ('teeth') separated by deep cleft-shaped gaps.

Many indisputable, $\mathrm{cm}$ - to $\mathrm{m}$-scale folds are exposed within ogive ridges and on their flanking surfaces; however, none have been found that form the ridge itself. Fold attitudes range from upright (Fig. 7B) to recumbent (Fig. 7A) and all are closed to isoclinal, similar-style (transitional from Ramsay class $1 \mathrm{C}-2$; Fig. 7B), disharmonic, intrafolial folds with gently curvilinear hinges. Many of the largest folds refold smaller folds around their hinges (Fig. 7C). When crease structures and clefts are restored many of the upright isoclines (e.g., Fig. 7B) become recumbent and the flow-banding sub-horizontal (cf. Smith and Houston, 1994).

\subsection{Viscosity measurements}

The viscosity of three variably pumiceous obsidians from the upper surface at Obsidian Dome were measured to constrain the temperature at which ductile folding of the upper surface could occur. Samples include FVP, CVP, and an avesicular obsidian (Table 1). Water contents $\left(\mathrm{H}_{2} \mathrm{O}_{\text {tot }} ; 3,570 \mathrm{~cm}^{-1}\right)$, and bubble volume, were determined for each sample using Fourier-transform infrared spectroscopy (FTIR), and density measurements after the methods in (Houghton and Wilson, 1989) and (Avard and Whittington, 2012). Viscosity measurements were made using a Theta Instruments Rheotronic III parallel-plate viscometer, under constant uniaxial compression with a mass of $1,500 \mathrm{~g}$, using six to eight isothermal holds at temperatures from $719.5^{\circ} \mathrm{C}$ to $900.4{ }^{\circ} \mathrm{C}$ with dwell times ranging from $\sim 8.0$ seconds to $\sim 7.6 \mathrm{~h}$ (Table 1 ).

The measured viscosities of dense obsidians are reproduced well (RMSD $=0.14-0.17 \log 10$ Pas) by the model of (Romine and Whittington, 2015; Fig. 8A), which was calibrated using an extensive dataset of measurements on similar high-silica rhyolites with low crystal volume fractions and low dissolved water contents. The measured viscosities of FVP and CVP are not reproduced well by the model, suggesting the addition of bubbles to the melt has a measurable effect on the viscosity of FVP and CVP. The observed viscosity of FVP is greater than the predicted viscosity from the model, as expected for quasi-rigid bubble behavior at low strain rates and capillary numbers $<1$ (Pal, 2003), while the viscosity of CVP is less than the predicted viscosity from the model, as expected for deforming bubbles at capillary numbers $>1$, achieved through larger radii and higher matrix viscosity (Fig. 8A).

Maxwell (1867) described the transition from purely viscous behavior to viscoelastic behavior, by relating the apparent viscosity of a material $\left(\eta_{\text {app }}\right)$ to the shear modulus $\left(G_{\infty}\right)$ to produce a relaxation time $\left(\tau_{\text {rel }}\right)$ that describes how quickly a liquid can dissipate a shear stress.

$\tau_{\text {rel }}=\frac{\eta_{a p p}}{G_{\infty}}$

For silicic melts, $G_{\infty}$ is $\sim 30 \mathrm{GPa}$, decreasing very slightly with increasing water content (Whittington et al., 2012). The Deborah number (De) is a convenient way to describe the likely deformation style of a silicate liquid by relating $\tau_{\text {rel }}$ to the time scale of deformation $\left(\tau_{\text {def }}\right)$ of the silicate liquid by:

$D e=\frac{\tau_{\text {rel }}}{\tau_{\text {def }}}$

where when $D e<0.001$ stress is dissipated primarily by viscous deformation, and when $D e>0.001$ the deformation style begins to transition to viscoelastic deformation until $D e=0.01$ when brittle deformation is expected (Cordonnier et al., 2012). We applied a range of $\tau_{\text {def }}$ values ( 0.01 to $10 \mathrm{yrs}$, intended to extend beyond the highest and lowest estimates of true emplacement timescales) to determine the likely temperature range for the onset of brittle deformation of the upper surface of Obsidian Dome (Fig. 7B). We estimate the onset of viscoelastic deformation $(D e=0.001)$ to be around $665^{\circ} \mathrm{C}$ and $710^{\circ} \mathrm{C}$ for CVP and FVP respectively, and brittle failure $\left(D e=0.01\right.$ ) to occur around $639^{\circ} \mathrm{C}$ and $684^{\circ} \mathrm{C}$ for CVP and FVP respectively.

\subsubsection{Cooling model}

At Obsidian Dome the best available estimates of magma storage eruption temperature are $900-950^{\circ} \mathrm{C}$ (ilmenite-magnetite equilibrium geothermometer Vogel et al., 1989), although eruption temperatures were likely lower, probably of the order of $810^{\circ} \mathrm{C}$ (CVP from Vogel et al., 1989). The new liquid-pyroxene thermometer from (Brugman and Till, 2019) with glass and pyroxene compositions from Vogel et al. (1989) yields an eruptive temperature of $792^{\circ} \mathrm{C}$. The cooling rate $(d T / d t)$ of the upper lava surface can be estimated using the values summarized in Supplemental Table 1 and the general equation:

$\frac{d T}{d t}=\frac{Q_{\text {rad }}+Q_{\text {conv }}+Q_{\text {cond }}}{\rho C_{P} \Delta y}$

where $\rho$ is density $\left(2350 \mathrm{~kg} \mathrm{~m}^{-3}\right), C_{P}$ is isobaric heat capacity (1225 $\mathrm{J} \mathrm{kg}^{-1} \mathrm{~K}^{-1}$ Hofmeister et al., 2016), and $\Delta y$ is the depth within the lava to reach the core temperature, and $Q_{\text {rad }}, Q_{\text {conv }}$, and $Q_{\text {cond }}$ are the radiative, convective, and conductive heat fluxes respectively, described by equations: 

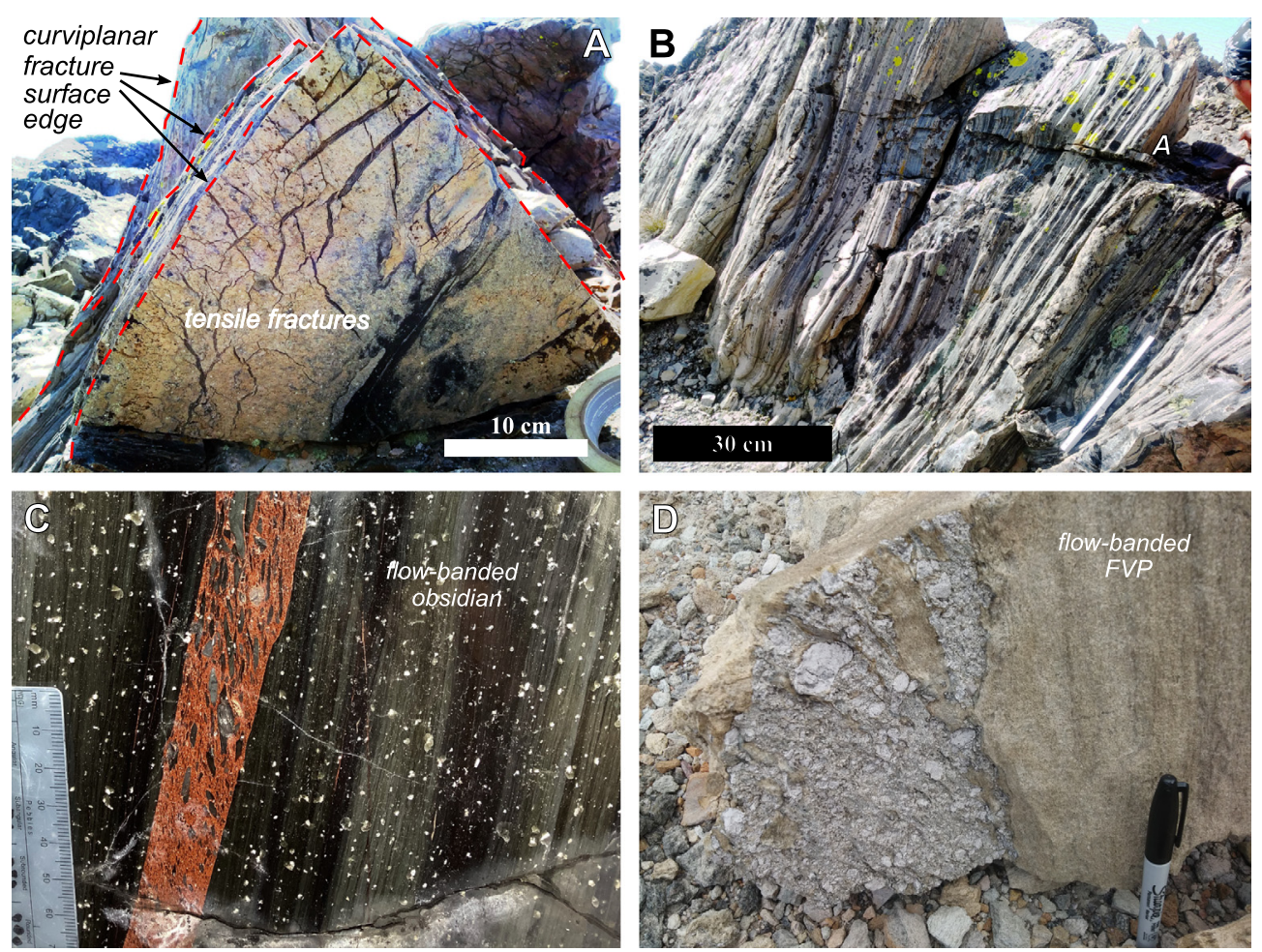

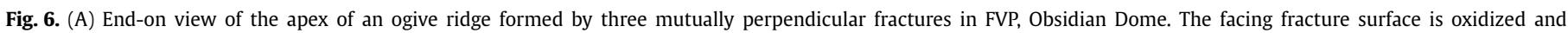

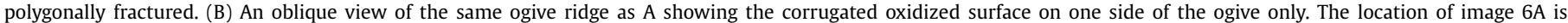

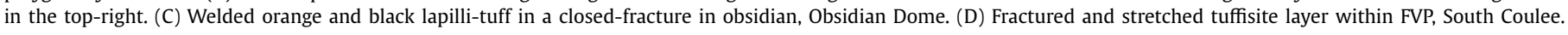
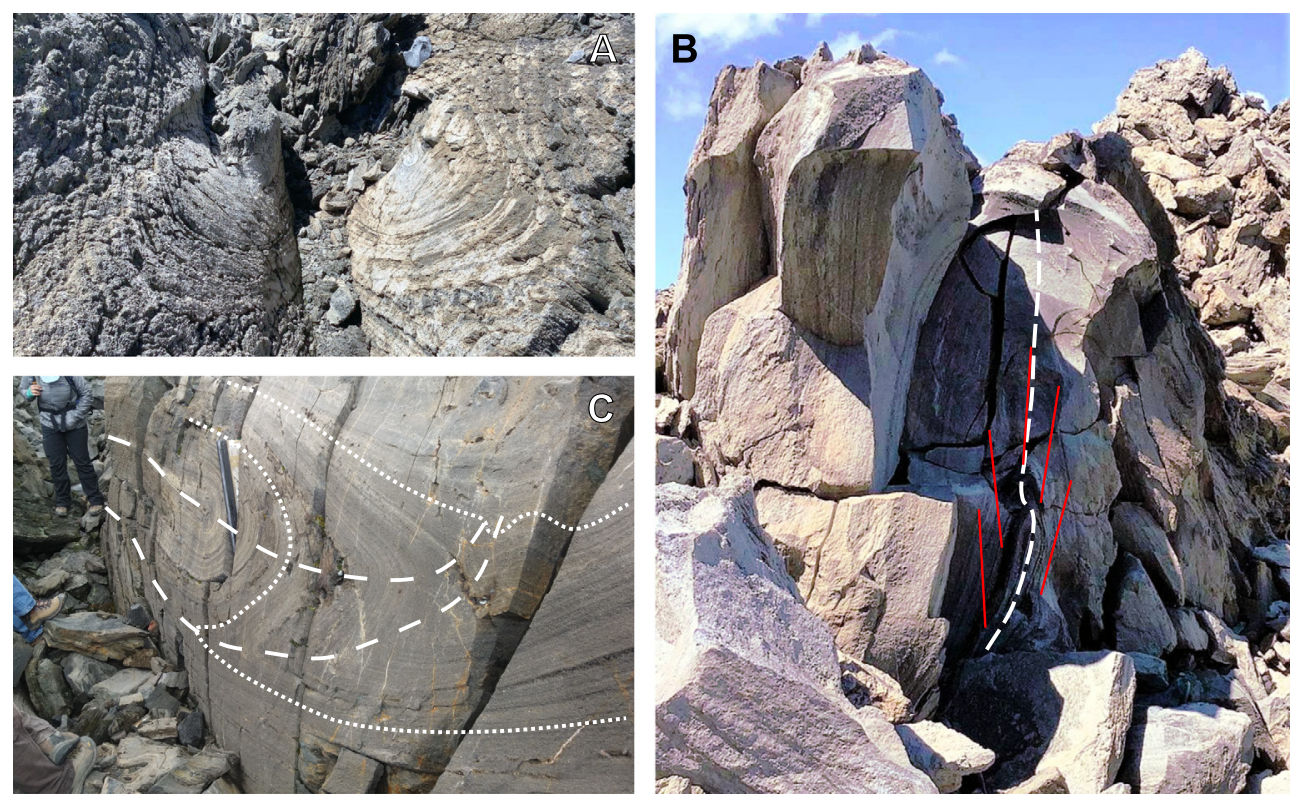

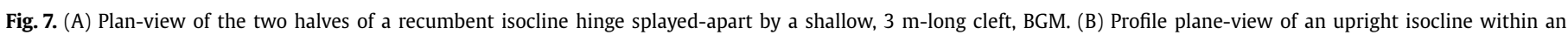

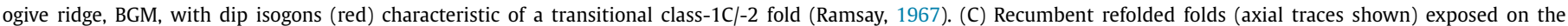
flank of a large crease structure, Obsidian Dome.

$$
\begin{aligned}
& Q_{\text {rad }}=\varepsilon \sigma_{S B}\left(T_{\text {crust }}^{4}-T_{\text {air }}^{4}\right) \\
& Q_{\text {conv }}=h_{c}\left(T_{\text {crust }}-T_{\text {air }}\right) \\
& Q_{\text {cond }}=-k \frac{T_{\text {core }}-T_{\text {base }}}{\sqrt{D \pi t}}
\end{aligned}
$$

Where $\varepsilon$ is the thermal emissivity (assumed to be $\sim 0.95$ ), $\sigma_{\mathrm{SB}}$ is the Stefan-Boltzmann constant $\left(5.67 \times 10^{-8} \mathrm{~W} \mathrm{~m}^{-2} \mathrm{~K}^{-4}\right), T_{\text {crust }}$ is the temperature of the lava crust ( $323 \mathrm{~K}$ to $573 \mathrm{~K}$ ), $T_{\text {air }}$ is the temperature of the air $(298 \mathrm{~K}), h_{c}$ is the convective heat transfer coefficient (10 to $150 \mathrm{~W} \mathrm{~m}^{-2} \mathrm{~K}^{-1}$ ), $k$ is the thermal conductivity (1.98 $\left.\mathrm{W} \mathrm{m}^{-1} \mathrm{~K}^{-1}\right), T_{\text {core }}$ is the internal temperature of the lava (1065 $\mathrm{K}$ to $1200 \mathrm{~K}$ ), $T_{\text {base }}$ is the temperature of the underlying ground $(298 \mathrm{~K}), D$ is the thermal diffusivity $\left(6.87 \times 10^{-7} \mathrm{~m}^{2} \mathrm{~s}^{-1}\right.$ Romine et al., 2012), and $t$ is time since emplacement. We assume no additional heating from crystallization or advection of additional magma into the lava. Quantities such as $C_{P}, D, \rho$ and $k$ are all temperature-dependent, but compared to the range of lava 
Table 1

Measured water content, porosity, and density of Obsidian Dome samples, and experimentally determined viscosities.

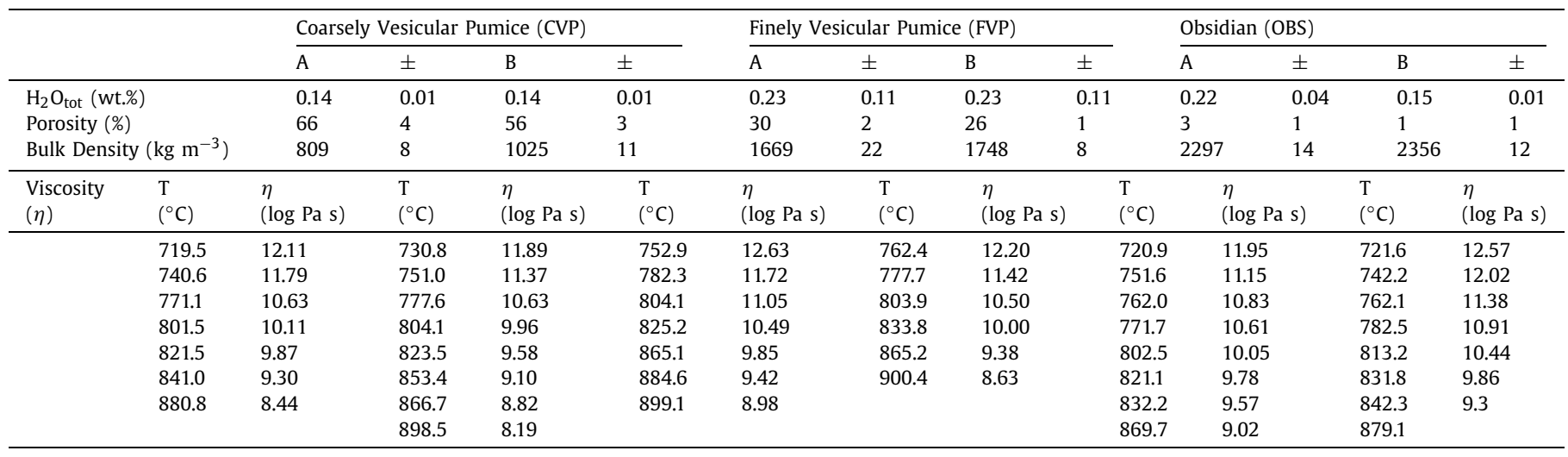
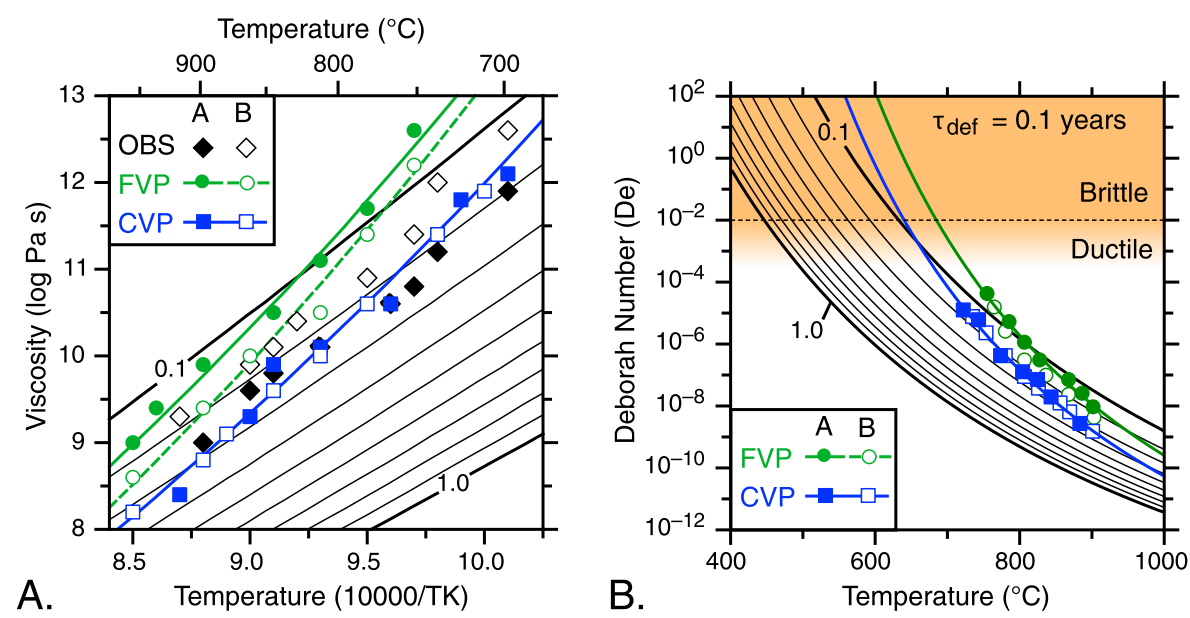

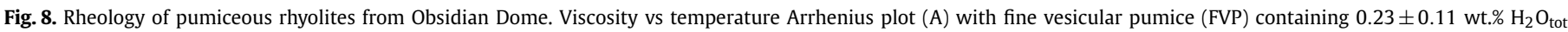

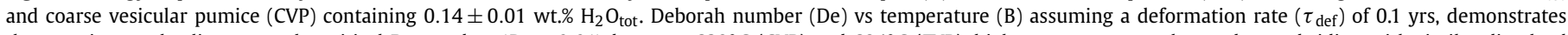

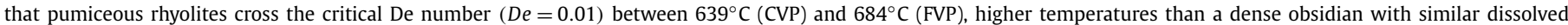

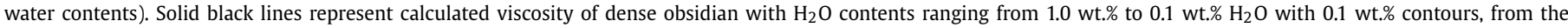
model of Romine and Whittington (2015). Dashed black lines and shading from white to orange in (B) represent transition zone between ductile and brittle deformation.

crust temperatures considered, the uncertainty introduced by using constant values is negligible in this case.

Solving equations (3) through (6) yields cooling rates $(d T / d t)$ of 0.18 to $2.5 \mathrm{~K} \mathrm{~min}^{-1}$ (Supplementary Fig. 2) The calculated cooling rates agree with experimentally determined cooling rates of silicic lavas reported by Gottsmann and Dingwell (2001) which range from 0.013 to $4.2 \mathrm{Kmin}^{-1}$ at $T_{g}$. Therefore, cooling at a rate of $0.18 \mathrm{~K} \mathrm{~min}^{-1}$ from an emplacement temperature of $792^{\circ} \mathrm{C}$ to the brittle-ductile transition temperature $\left(684^{\circ} \mathrm{C}\right)$ for FVP in the upper crust of the lava requires $\sim 10 \mathrm{~h}$. Using a lower temperature for the brittle-ductile transition, which could occur as low as $\sim 614^{\circ} \mathrm{C}$ for avesicular obsidian containing 0.2 wt. $\% \mathrm{H}_{2} \mathrm{O}$ (Fig. 8B), would require $\sim 16$ h. However, the surface layers of most rhyolite lavas are FVP (Ramsey and Fink, 1999), so we prefer the more rapid estimate. Note that we assume low values for $h_{c}$ $\left(10 \mathrm{~W} \mathrm{~m}^{-2} \mathrm{~K}^{-1}\right)$, crust temperature (323 $\mathrm{K}$ ), and eruption temperature $(1065 \mathrm{~K})$, which results in a conservative estimate for cooling rates at the surface of the flow. Possible values of $h_{c}$ range from 10 to $150 \mathrm{~W} \mathrm{~m}^{-2} \mathrm{~K}^{-1}$ (Harris, 2013). Assuming both very efficient convective cooling $\left(h_{c}=150 \mathrm{~W} \mathrm{~m}^{-2} \mathrm{~K}^{-1}\right)$, a hot crust $(573 \mathrm{~K})$, and a higher emplacement temperature $(1200 \mathrm{~K})$ with a cooling rate of $2.5 \mathrm{~K} \mathrm{~min}^{-1}$, the timescale over which the upper surface remains ductile and capable of folding would be only $\sim 100 \mathrm{~min}$.

\subsection{Stress}

Using published data to constrain the tensile strengths of pumiceous silicic magmas, we model the 2D stress conditions within the uppermost layers of a lava flow. The ranges of tensile $\left(\sigma_{\mathrm{t}}\right)$ and uniaxial compressive strengths $\left(\sigma_{\mathrm{c}}\right)$ for crystal-poor, silicic volcanic rocks are inversely proportional to porosity and bubble size (e.g., Harnett et al., 2019; Heap et al., 2017). Pumiceous materials can have very low $\sigma_{c}(<100 \mathrm{MPa}$ at $25-40 \%$ bubbles (Heap et al., 2017); 5-50 MPa at 20-40\% pore space (Harnett et al., 2019); 2-12 MPa at 30-50\% porosity (Quane and Russell, 2003) whereas dense obsidian ( $<5 \%$ bubbles) can be very strong (350-600 MPa Heap et al., 2017; Tuffen et al., 2008). Tensile strengths for rhyolites vary from $\sim 50$ MPa for LGM rhyolite (Webb and Dingwell, 1990) to 3-8 MPa for felsite (Bauer et al., 2018) and 3-6 MPa for dacitic lavas with rhyolitic glass compositions (Hornby et al., 2019). While $\sigma_{t}$ is much less well constrained, it is usually $\approx 10-15$ times weaker than $\sigma_{c}$ in isotropic rocks (Perras and Diederichs, 2014), and silicic volcanic rocks generally follow this pattern (Harnett et al., 2019).

A $50 \mathrm{~m}$-thick, horizontal lava composed of a $10 \mathrm{~m}$-thickness of FVP and $40 \mathrm{~m}$ of obsidian (mean density $(\rho) 2,188 \mathrm{~kg} / \mathrm{m}^{3}$ ) will experience a lithostatic stress of $1.07 \mathrm{MPa}$ at its base. At this pressure water solubility at $80^{\circ} \mathrm{C}$ is $\sim 0.35 \mathrm{wt} . \%$ (Liu et al., 2005), assuming 

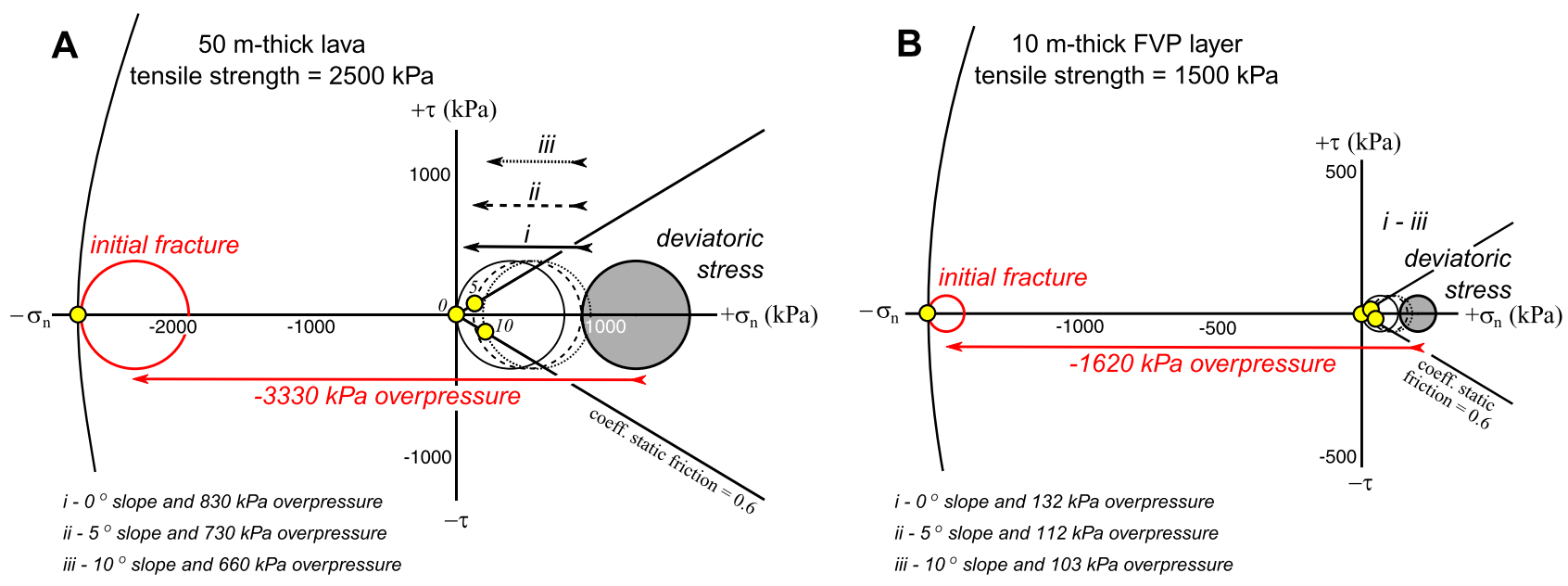

Fig. 9. Mohr stress circles. Stress conditions and failure envelopes for (A) a 50 m-thick composite layer and (B) a 10 m-thick FVP layer.

solubility is well-calibrated at these low pressures. Under uniaxial stress and for an assumed Poisson's ratio $(v)$ of 0.25 (Perras and Diederichs, 2014) the additional deviatoric stresses $\left(\sigma_{1}^{\prime}, \sigma_{2}^{\prime}, \sigma_{3}^{\prime}\right)$ are calculated as:

$\sigma_{1}^{\prime}=\frac{2(1-2 v)}{3(1-v)} \cdot \rho \cdot g \cdot h$

$\sigma_{2}^{\prime}=\sigma_{3}^{\prime}=-\frac{(1-2 v)}{3(1-v)} \cdot \rho \cdot g \cdot h$

The maximum stress is $1.55 \mathrm{MPa}$ and the intermediate and minimum deviatoric stresses are $0.83 \mathrm{MPa}$ producing a differential stress of $0.72 \mathrm{MPa}$ and maximum shear stress ( $\tau_{\max }$ ) of $0.36 \mathrm{MPa}$. Mohr-Coulomb (tensile) failure at $\sim-2.5 \mathrm{MPa}$ is therefore induced by an overpressure $\left(\sigma_{P}\right)$ of $\geq 3.33 \mathrm{MPa}$ (Fig. 9A). Such an overpressure requires $0.63 \mathrm{wt} . \% \mathrm{H}_{2} \mathrm{O}$ still dissolved at $800^{\circ} \mathrm{C}$. Obsidians with $\sim 0.6$ wt.\% $\mathrm{H}_{2} \mathrm{O}$ still dissolved are quite common at the Mono Craters (Romine and Whittington, 2015); therefore, it is very plausible that $\sim 3 \mathrm{MPa}$ of pore fluid overpressure would have existed. If only the $10 \mathrm{~m}$-thick FVP layer with an assumed tensile strength of $\sim 1.5 \mathrm{MPa}$ is considered, $\sigma_{P}=\sim 1.6 \mathrm{MPa}$ is necessary for tensile fracture (Fig. 9B), requiring only 0.44 wt.\% $\mathrm{H}_{2} \mathrm{O}$ still dissolved.

\subsubsection{Effect of slope}

Lavas on a slope $(\alpha)$ will experience an additional, weaker tensile stress following from:

$\sigma_{\text {slope }}=\rho . g . h . \sin \alpha$

Thus, the same $50 \mathrm{~m}$-thick lava will experience an additional $\sigma_{n}=22 \mathrm{kPa}$ and $\tau=72 \mathrm{kPa}$ on a $5^{\circ}$ slope and $\sigma_{n}=47 \mathrm{kPa}$ and $\tau=139 \mathrm{kPa}$ on a $10^{\circ}$ slope $\left(\sim 18 \mathrm{kPa} /{ }^{\circ}\right)$. The $10 \mathrm{~m}$-thick FVP layer will gain an additional $\sigma_{\mathrm{n}}=10 \mathrm{kPa}$ and $\tau=5 \mathrm{kPa}$ on a $5^{\circ}$ slope, and $\sigma_{\mathrm{n}}=10 \mathrm{kPa}$ and $\tau=20 \mathrm{kPa}$ on a $10^{\circ}$ slope $\left(\sim 3 \mathrm{kPa} /{ }^{\circ}\right)$. Underlying slopes beneath the Holocene lavas in California and Oregon are measured to range from $1^{\circ}$ to $12^{\circ}$.

Assuming a coefficient of static friction of $0.6, \sigma_{\mathrm{P}} \geq 0.83 \mathrm{MPa}$ is required to drive continued or renewed dilation across pre-existing fractures in horizontal $50 \mathrm{~m}$-thick lava. The additional stress required ( $\sigma_{\mathrm{P}}$ or $\sigma_{\text {slope }}$ ) decreases to $0.73 \mathrm{MPa}$ on a $5^{\circ}$ slope (Fig. $9 \mathrm{~A}$ ), and to $0.66 \mathrm{MPa}$ on a $10^{\circ}$ slope, and fractures will evolve to mode$\mathrm{I} /$-II hybrids. For the $10 \mathrm{~m}$-thick FVP layer $0^{\circ}, 5^{\circ}$ (Fig. 9B), and $10^{\circ}$ slopes require additional stresses of $132 \mathrm{kPa}, 112 \mathrm{kPa}$, and $103 \mathrm{kPa}$, respectively. Therefore, $\sigma_{\text {slope }}$ is insufficient to reactivate fractures post-emplacement and post-vesiculation of the lava.

Given the very low tensile strengths of volcanic glasses (i.e. below $T_{g}$ ), and especially when they experience overpressures, it is very unlikely that sufficient differential stress can develop at the upper surface of a lava to allow for ductile-compressional flow unless it is an incredibly thick layer (100 s of meters) and strain rates are exceptionally low (e.g., tectonic rates; $10^{-14}-10^{-15} \mathrm{~s}^{-1}$; Fagereng and Biggs, 2018). The strain rates within silicic lavas range from $10^{-3}$ to $10^{-6} \mathrm{~s}^{-1}$ (Byrnes et al., 1997; Rust et al., 2003), but are difficult to estimate due to the absence of reliable strain markers and poor knowledge of emplacement timescales. Anomalously thick (150-300 m-thick) silicic lavas have been documented in South Australia and the Snake River Plain, Idaho that are about twice as thick as typical silicic lavas and 10-100 times more voluminous (Branney et al., 2008). The thin upper surfaces of the Holocene lavas analyzed meet neither of these criteria.

\section{Discussion}

Our results are consistent with neither ductile deformation nor compressional stresses at the upper surfaces of silicic lavas, rather they are explained by brittle-tensile deformation. This contradicts existing models for silicic lava emplacement and analyses that rely on the upper surfaces of lavas being folded. A review of fieldbased descriptions and structural studies of silicic lavas in Australia (Smith and Houston, 1994), Chile (Tuffen et al., 2013), Italy (Bullock et al., 2018; Cioni and Funedda, 2005), Japan (Maeno and Taniguchi, 2006), New Zealand (Stevens, 2002), and the United States (Fink, 1980b, 1983; Leggett et al., 2020; Christiansen and Lipman, 1966; Loney, 1968) fails to identify any 10-20 m-scale, upright, buckle-style folds forming ogives, and instead emphasizes the predominance of brittle deformation and uniformly steep flowbanding. Smaller folds abound (e.g., Smith and Houston, 1994; Christiansen and Lipman, 1966; Castro and Cashman, 1999), but no compelling evidence is presented to demonstrate that ogives are continuous buckle-style folds of a single surface akin to pāhoehoe ropes (cf. Fink, 1980a). The interpreted field images and few crosssections available infer lateral continuity of a layer between ogives and infer that intervening 'synforms' are talus-filled and obscured (Fink, 1983; Tuffen et al., 2013). However, where large-scale ogiveforming folds are inferred, the fold closures are projected between adjacent outcrops of similar lithofacies and are not observed (e.g., Fink, 1983).

\subsection{A brittle-tensile deformation model for ogive formation}

Our results imply that brittle-tensile deformation is the most important form of deformation active on the upper surfaces of lavas as they are emplaced. The primary data showing this are: 
(1) the fracture-bound nature of ogive ridges and the similarity of ogive troughs to crease structures; (2) the ubiquitous presence of tensile fractures and the absence of large-scale buckle-style folds; (3) the short time window ( $<10 \mathrm{~h}$ ) for ductile deformation; and (4) the inability of low-tensile strength FVP to accumulate enough stress to drive compression. If the surface layer is only ductile for a few hours to about one day, compared to $\sim 200-230$ days for the emplacement of Obsidian Dome (Fink and Griffiths, 1998) and $\sim 550$ days at Cordón Caulle (Tuffen et al., 2013), and if ogives are interpreted as folds, then the presence of ogives far from the vent implies either very rapid lava emplacement prior to folding in situ, or formation near the vent and passive transport to the margins. Neither seems feasible, and the inescapable conclusion of the field observations and rheological evidence is that ogives are brittle structures formed by extension.

4.1.1. Pervasive formation of crease structures throughout emplacement

The interpretation of ogive troughs as splayed tensile fractures (mode-I) rather than synforms is controversial, and the subject of on-going study that will further develop the hypothesis. However, our data are consistent with ubiquitous tensile fracturing of the upper surface where weak, pumiceous FVP is widespread (Fig. 9) as demonstrated in many analog models (e.g., Fink and Griffiths, 1992; Lescinsky and Merle, 2005). Stress accumulates in FVP due to continued vesiculation and volume increase, and is increased by slope and, presumably, by motions within the underlying obsidian (e.g., lateral and vertical changes in flow direction and velocity including inflation and deflation). In our model, pervasive and repeated fracturing of the upper surface produces straight, cleftshaped, splaying fractures (Fig. 4C; 6A-B; 7A) - crease structures (e.g., Fig. 2D) - that are themselves then disrupted by viscous relaxation and later fracturing. Fractures initiate in the weak FVP layer and propagate into the underlying obsidian. We interpret the red oxidized surfaces and tuffisite and lapilli-tuff layers (Fig. 6) as evidence for venting of magmatic volatiles and tephra along the crease structures. The tensile fractures open parallel to the local stretching direction and obliquely intersect each other along strike (Fig. 4B). Once formed, fractures are permanent weaknesses reactivated on slopes $>5^{\circ}$ experiencing sustained vesiculation (Fig. 9B). As vesiculation and cooling progress the depth to the FVP-obsidian boundary increases, leading to longer and deeper crease structures spaced further apart. The final and largest crease structures (cf. Fink, 1983; Anderson and Fink, 1992; Fig. 2D) are the least deformed and are therefore the most easily recognized. Our observations and those of Anderson and Fink (1992) and Lescinsky et al. (2007) show that the largest, simplest crease structures form oblique to the ogives and often in en echelon sets. We interpret the increasing discordance between ogives ('early' crease structures) and larger, later crease structures to reflect the gradual lateral spreading of the lava sheet itself (i.e. external tensile stresses; Merle, 1998) rather than deformation limited to the upper surface by vesiculation of FVP (i.e. internal stresses) and proximity to the flow-front. This is simpler than the interpretation of Lescinsky et al. (2007) that calls for two generations of crease structures, parallel and radiating, respectively, to overprint three generations of ogive ridge and trough fold pairs, each increasing in wavelength and amplitude during cooling.

\subsubsection{Viscous relaxation of crease structures}

Crease structures in 1980 Mount St. Helens dacite penetrated deeply enough to expose incandescent lava (Anderson and Fink, 1992) indicating that hot ( $\geq T_{g}$ ) lava was being deformed brittlely. When the tensile stress during fracture propagation is relieved, the surrounding $>T_{g}$ lava may partly (Fig. 6B) or completely (Fig. 6C) relax and close the fracture up, trapping tuffisite (Fig. 6D) and welded lapilli-tuff (Fig. 6C); the FVP cannot relax. Viscous relax- ation probably removes $\mathrm{mm}$ - to $\mathrm{cm}$-scale striations on fracture surfaces, explaining why they are absent on most surfaces except those of the largest crease structures. The viscous relaxation of the fracture walls produces the cuspate cleft-shape as the distance required to close the fracture and the ability of the obsidian to relax are both greatest close to the tip-line. If this interpretation is correct, it may be possible to constrain a viscosity-depth profile based on the curvature of a crease structure wall.

\subsubsection{Testing between fold- and fracture-models by structural restoration}

In the absence of ogives obviously being folds, some of the most compelling evidence for ductile compression comes from the published maps and cross-sections at LGM (Fink, 1983; Fink and Anderson, 2017) and Rocche Rosse, Italy (Bullock et al., 2018). However, in both cases the ogive-scale fold closures are inferred, and the LGM cross-section is drawn along the axis of an ogive rather than perpendicular to it, and therefore, cannot be restored in a meaningful way. Instead, it emphasizes the presence of regularly spaced clefts perpendicular to the ogive ridge and line of section, and the presence of séracs, similar to Fig. 4C.

In Fig. 10 we contrast our interpretation with the paradigm of folding through conceptual restorations of a typical ogive ridge-trough-ridge outcrop (A). Interpreting the ridges as upright, buckle-style antiforms and the trough as a synform (B1) requires that the folds be restored by stretching the upper surface. Doing so rotates the flow-banding to sub-vertical and does not allow marker bands on either side of the trough to match (B2). The vertical flow-banding and intrafolial folds $\left(F_{1}\right)$ must be truncated by a sub-horizontal erosion surface that is subsequently folded $\left(F_{3}\right)$ to become the present-day undulating surface. The marker bands can only be matched together by a second, otherwise unknown phase of folding $\left(F_{2}\right)$ before erosion to make the sub-horizontal surface. In contrast, interpreting the ogive trough as a crease structure (C1) requires restoration by shortening the upper surface and closingup the fracture (C2). This matches the marker bands and requires only one deformation event. It also restores the flow-banding to sub-horizontal and the dominant fold attitude to recumbent. Doing so helps to reconcile previously contradicting observations of finite shear strain in lavas, where layer-parallel shortening (Fink, 1980a), possibly modified by non-coaxial rotation of the ogives (Farrell et al., 2018) is inconsistent with the sub-horizontal extensional magnetic fabrics (Cañón-Tapia and Castro, 2004) and strain recorded in microlite orientations (Castro et al., 2002; Manga et al., 2018) at Obsidian Dome.

\subsubsection{Ogives and paleotopography}

The relationship between ogives and the margins of lavas that have impinged on paleotopography is another useful test. If ogives formed as folds in compression, then they should be well-developed where the lava abuts a topographic barrier and potentially less well-developed or absent where the lava is unconstrained. Examination of silicic lavas in the western US failed to identify any that have unambiguously impounded against a preexisting terminal barrier and stopped flowing. In nearly all cases the distal margin, and often one or more sides, are not confined (e.g., Fig. 1C), implying that the advance of silicic lavas is self-limited. For example, the Inter Lake, Obsidian Dome, LGM, and BGM lavas all show more weakly developed ogives, or none at all, where they impinged on a topographic high (Fig. 4A). In each case ogives are much better developed where the lavas have flowed around and away from the paleotopographic obstruction, and the lobes formed are no less ornamented with ogives than unconstrained lavas like the Medicine Lake dacite. The best developed ogives correspond with the greatest underlying slope angle and, presumably, flow velocity, where tensile stresses are greatest. 


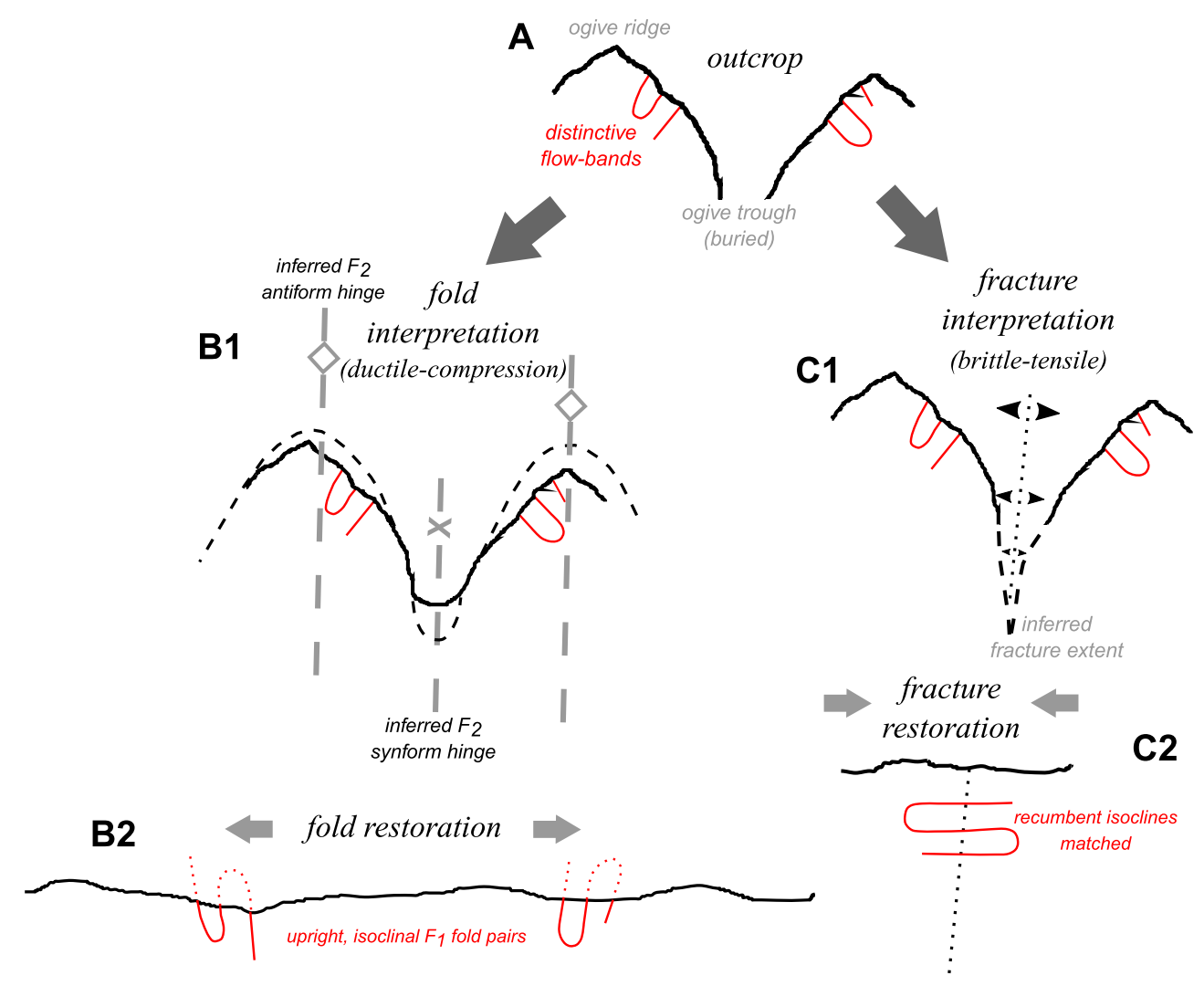

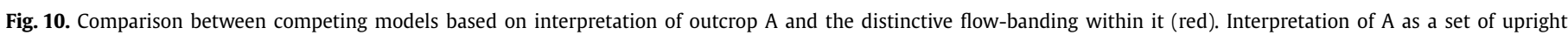

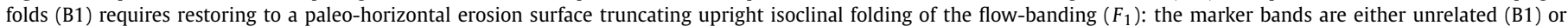

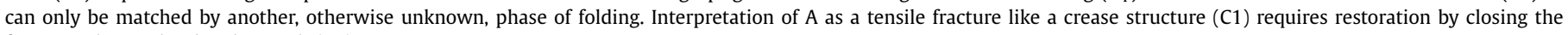
fracture: the marker bands match (C2).

The Inter Lake lava bifurcated where it impinged against an older volcanic cone (Fig. 4A) generating two lobes that flowed away from one another; the area where they diverge is characterized by flow-perpendicular tensile fractures, not ogives parallel to the topographic barrier. The only case where well-developed ogives are spatially associated with a prominent topographic barrier is the northeast lobe of the Big Obsidian Flow (Fig. 1B) but field evidence indicates that the ogives there are defined by tensile fractures.

\subsubsection{Parabolic ogives}

The observation that ogives become more parabolic further from the vent in coulées (Fig. 5) is yet another test. If the ogives are continuous buckle-style folds, each fold should be stretched downflow (greatest stretching along the thalweg), attenuated, and be itself folded about a vertical axis that intersects the thalweg (e.g., Farrell et al., 2018). Farrell et al. (2018) recognized it is impossible to impose heterogenous non-coaxial shear strain on a cylindrical, upright, buckle-style (Ramsay class 1B) fold without it becoming progressively more flattened and inclined (Mukherjee et al., 2016), non-cylindrical, and the folds evolving towards similarstyle (class 2). This would mean that parabolic ogives could no longer be interpreted for viscosity using fold-theory techniques (cf. Fink, 1980a; Gregg et al., 1998) that are only applicable to bucklefolds. Many $\mathrm{cm}$ - and $\mathrm{m}$-scale folds are transitional between classes 1C and 2 (e.g., Fig. 7B), but the absence of class 1B folds and understanding that intrafolial folds can initiate as class $1 \mathrm{C}$ and class 2 folds (Mukherjee et al., 2016) suggests that such an evolution has not taken place.

Interpreting the ogives as ridges separated by crease structures removes the need for a vertical axis rotation component and can explain why the ogives become more parabolic downslope because the flow velocity is greatest along the thalweg. This means that as the coulee flow front advances the mid-part in the thalweg advances faster than the margins, and the margins may be extending perpendicular to the thalweg. This is analogous to glaciers and namakiers where the mid-channel advances fastest and furthest. Both glaciers (Hambrey and Lawson, 2000) and namakiers (Talbot and Pohjola, 2009) are characterized by crevasses on their upper surfaces (Colgan et al., 2016), not folds and there, ogives are often interpreted as closed, discolored crevasses, and are cross-cut by large, open, en echelon and radial crevasses. Lavas differ chiefly in that they are insoluble, and their rheology changes non-linearly over several orders of magnitude (Fig. 8) between eruption and coming to rest.

\subsection{The 2011-13 Cordón Caulle Obsidian lava: ogive formation observed}

The only modern observation and documentation of the emplacement of an extensive, rhyolitic lava was during the 2011-13 eruption of Puyehue - Cordón Caulle, Chile (Tuffen et al., 2013), where ogive development was also observed for the first time contemporaneous with crease structure formation (Farquharson et al., 2015). The $\sim 18$ month eruption produced an extensive lava that continued to advance for 6-8 months after the eruption ceased, challenging previous interpretations of silicic lava emplacement timescales and styles (Tuffen et al., 2013; Farquharson et al., 2015), and understanding of the associated volcanic hazards. Prominent parabolic ogives $\leq 500 \mathrm{~m}$ in length are present in the central parts of the northern and southern flow fields (Tuffen et al., 2013) and numerous smaller ( $\sim 50$ to $150 \mathrm{~m}$-long and $\sim 5$ to $25 \mathrm{~m}$-wide) ogive ridges were observed to develop in the eastern and north- 
ern lobes (Farquharson et al., 2015), respectively. Although not the primary focus of their study, Farquharson et al. (2015) inferred the ridges formed as folds at the upper surface during inflation and advance of the underlying lava.

The irregular shapes of the ogives at Cordón Caulle, combined with their rapid formation and subsequent stability (Farquharson et al., 2015) are not easily explained by progressive ductile flow and folding of the upper surface. Review of Farquharson et al.'s (2015) figures 5 and 7 show that topographically significant ridges ( $\geq 6 \mathrm{~m}$-high) formed very quickly ( $\leq 3 \mathrm{~h}$ to $\leq 6$ days, respectively) in the eastern and northern lobes. Ridges and troughs formed early and before $\sim 10-20 \mathrm{~m}$ of inflation of the lobes but the difference in elevation between the tops of the ridges and the bottoms of troughs ( $\sim 10-12 \mathrm{~m}$ ) did not change, even after $1 \mathrm{yr}$ and $20 \mathrm{~m}$ of inflation. If these are in fact folds, then $50 \%$ shortening of a $\geq 2 \mathrm{~m}$ thick layer in the eastern lobe in $\leq 3 \mathrm{~h}$ is implied by ogives with wavelengths and amplitudes of $\sim 5 \mathrm{~m}$. Finally, rather than discreet continuous ridges and troughs, the ogives pre- and post-inflation are defined by discontinuous, often en echelon, equant or weaklyelongate elevated blocks and depressions separated along strike by areas that have experienced little or no vertical displacement (e.g., figure 5 of Farquharson et al., 2015): they do not exhibit as harmonic, cylindrical folds like in pāhoehoe, and are instead like the straight, steep-sided, ogive segments identified in this study.

\subsection{Implications for studies of remote lavas}

Our data contradict interpretations that ogives are large-scale, buckle-style folds on the upper surfaces of silicic lavas, and therefore, estimates of viscosity and composition based on fold theory (e.g., Fink, 1980a; Gregg et al., 1998; Maeno and Taniguchi, 2006; Farrell et al., 2018; Deardorff et al., 2019) are invalid. For example, Gregg et al. (1998) produced a model where the decreasing ratio of the amplitudes of different generations and sizes of ropes and ogives $(\Lambda)$ were related to more evolved compositions. However, our efforts to apply this technique along eight transects of $1 \mathrm{~m}$ resolution airborne lidar-derived digital elevation models across Obsidian Dome produced highly variable values of $\Lambda$ with mean inferred viscosities more like basaltic lavas (Supplementary Material A). We attribute this to smoothing of $<5 \mathrm{~m}$-scale, rugged, fracture-bound ridges giving the appearance of continuous, harmonic 2-5 m-wavelength folds. Running the same analyses with lower resolution radar altimetry data returns mean inferred viscosities like rhyolite.

Lescinsky et al. (2007) interpreted the presence of three generations of folds on the Medicine Lake dacite as evidence for a sustained, stable rheology during deformation. They identified latestage, large-scale, crease structures disrupting the three-generation ogive pattern, and described a complex, multi-stage emplacement evolution. Our analyses at Medicine Lake and from imagery and sUAS-derived models show that the three generations of folds are different widths of fracture-bound ridges (e.g., Fig. 4C). Review of Lescinsky et al.'s (2007) topographic profiles suggests that the disharmonic and rugged waveforms are better interpreted as multi-scale fracture-bound ridges rather than folds. Deardorff et al. (2019) applied Fourier transform analysis of ogives as waveforms and confirmed a correlation between wavelength and effective viscosity. However, they identified a significant overlap in data for compositions ranging from basaltic andesite to rhyolite, as well as numerous examples that had higher or lower viscosities than predicted. They attributed some of these discrepancies to eruption conditions specific to each lava. We propose that uncertainties in these models result from the flawed starting assumption that ogives are folds, and that results of these and similar studies need re-examination.
Despite the common observation from aerial images that ogives look like pāhoehoe ropes (Fink, 1980b; Fink and Fletcher, 1978), they cannot form in the same way, at least not on Earth's surface. However, deep-submarine silicic lavas and those on Venus (e.g., 'festoon flows' Bridges, 1997) may behave differently where volatile exsolution, and therefore vesiculation, and cooling rates are suppressed. Suppressed vesiculation may prevent formation of a thick FVP carapace and sustain ductile flow, and ductile deformation may affect the upper surface; however, extensional forces are likely to remain dominant in most scenarios. Therefore, ogives mapped on submarine and Venusian lavas may be structurally more like sets of extensional core complexes (Cooper et al., 2017). Ogives that are interpreted as folds on cryolavas and glaciers on other planetary bodies may warrant reexamination.

Other extraterrestrial features are analogous to how we interpret ogives. 'Pancake domes' (Fink et al., 1993) are another potential silicic lava type on Venus and are characterized by radial, rectilinear, and polygonal fracture patterns (Stofan et al., 2000) rather than circumferential ogives, suggesting that they experienced uniaxial compression under gravity with corresponding radial, brittle extension and advance at the margins (e.g., Merle, 1998). We see similar rectilinear and radial fracture patterns developed in terrestrial silicic lavas (e.g., Medicine Lake dacite; Fig. 4C). Ridge-andtrough terrains on Enceladus, Europa, Ganymede, and Miranda are interpreted as horst-and-graben features due to extension over a convecting interior (Barr and Hammond, 2015).

\section{Summary}

Ogives are prominent surface features characteristic of silicic lavas. Field observations of ogives and experimental data are best explained by the upper surfaces silicic lavas deforming brittlely and under extension, during emplacement. The upper parts of silicic lavas cool, vesiculate, and outgas readily, and the resulting vitric and pumiceous lithofacies have very low tensile strengths leading to pervasive vesiculation-driven tensile failure. This contradicts many previous studies that emphasize ductile compression and folding of the upper lava surfaces. Crease structures are ubiquitous at a range of scales and are responsible for disrupting and tilting the surface to form the ogives and to rotate flow-banding from horizontal to vertical. Recognition that large-scale folding of the upper surface does not occur makes numerical analysis and interpretation of fold wavelengths and amplitudes redundant.

\section{CRediT authorship contribution statement}

Graham D.M. Andrews: Conceptualization, Data curation, Formal analysis, Funding acquisition, Investigation, Methodology, Project administration, Supervision, Visualization, Writing - original draft, Writing - review \& editing. Stuart M. Kenderes: Conceptualization, Formal analysis, Investigation, Methodology, Visualization, Writing - original draft, Writing - review \& editing. Alan G. Whittington: Conceptualization, Formal analysis, Funding acquisition, Methodology, Project administration, Supervision, Visualization, Writing - original draft, Writing - review \& editing. Shelby L. Isom: Conceptualization, Investigation, Visualization, Writing - review \& editing. Sarah R. Brown: Investigation, Methodology, Writing - review \& editing. Holly D. Pettus: Investigation. Brenna G. Cole: Investigation. Kailee J. Gokey: Investigation.

\section{Declaration of competing interest}

The authors declare that they have no known competing financial interests or personal relationships that could have appeared to influence the work reported in this paper. 


\section{Acknowledgements}

This research was supported by The National Science Foundation through awards EAR 1725131 and EAR 1935764 to GA and EAR 1724581 to AW, and the John C. and Mildred Ludlum Geology Endowment to SI. Reviews by Lis Gallant and James Farrell, and editing by Heather Handley, improved the manuscript immensely. The authors benefited from discussions with Kenneth Befus, Tyler Leggett, Kelly Russell, Amy Ryan, and Stephan Kolzenburg.

\section{Appendix A. Supplementary material}

Supplementary material related to this article can be found online at https://doi.org/10.1016/j.epsl.2020.116643.

\section{References}

Anderson, S.W., Fink, J.H., 1992. Crease structures: indicators of emplacement rates and surface stress regimes of lava flows. Geol. Soc. Am. Bull. 104, 615-625. https://doi.org/10.1130/0016-7606(1992)104<0615:CSIOER>2.3.CO;2.

Anderson, S.W., Stofan, E.R., Plaut, J.J., Crown, D.A., 1998. Block size distributions on silicic lava flow surfaces: implications for emplacement conditions. Geol. Soc. Am. Bull. 110, 1258-1267.

Avard, G., Whittington, A.G., 2012. Rheology of arc dacite lavas: experimental determination at low strain rates. Bull. Volcanol. 74, 1039-1056. https://doi.org/10. 1007/s00445-012-584-2.

Barr, A.C., Hammond, N.P., 2015. A common origin for ridge-and-trough terrain on icy satellites by sluggish lid convection. Phys. Earth Planet. Inter. 249, 18-27.

Barr, A.C., Preuss, L.J., 2010. On the origin of south polar folds on Enceladus. Icarus 208, 499-503.

Bauer, S.J., Barrow, P., Robbins, A., Hileman, M., 2018. Mechanical and fluid flow properties of basaltic andesite and rhyolite analogue rocks. Sandia National Laboratories Fallon FORGE: analogue outcrop samples [data set]. Retrieved from. http://gdr.openei.org/submissions/1029.

Baum, B.A., Krantz, W.B., Fink, J.H., Dickinson, R.E., 1989. Taylor instability in rhyolite lava flows. J. Geophys. Res. 94, B5:5815-B5:5828.

Branney, M.J., Bonnichsen, B., Andrews, G.D.M., Ellis, B., Barry, T.L., McCurry, M., 2008. 'Snake River (SR)-type' volcanism at the Yellowstone hotspot track: distinctive products from unusual, high-temperature silicic super-eruptions. Bull. Volcanol. 70, 293-314

Bridges, N.T., 1997. Ambient effects on basalt and rhyolite lavas under Venusian, subaerial, and subaqueous conditions. J. Geophys. Res. 102, 9243-9255. https:// doi.org/10.1029/97JE00390.

Brugman, K.K., Till, C.B., 2019. A low-aluminum clinopyroxene-liquid geothermometer for high-silica magmatic systems. Am. Mineral. 104, 996-1004. https:// doi.org/10.2138/am-2019-6842.

Bullock, L.A., Gertisser, R., O'Driscoll, B., 2018. Emplacement of the Rocche Rosse rhyolite lava flow (Lipari, Aeolian Islands). Bull. Volcanol. 80, 48. https://doi.org/ 10.1007/s00445-018-1222-4.

Butler, R.W.H., Bond, C.E., Cooper, M.A., Watkins, H., 2019. Fold-thrust structures where have all the buckles gone? In: Bond, C.E., Lebit, H.D. (Eds.), Folding and Fracturing of Rocks: 50 Years of Research Since the Seminal Text Book of J. G. Ramsay. Geological Society London, Special Publications, p. 487.

Byrnes, J.M., Crown, D.A., Plaut, J.J., Anderson, S.W., 1997. Compressional flow ridges: implications for analysis of planetary lava flows. In: 28th Annual Lunar and Planetary Science Conference, March 17-21, 1997, Houston, TX

Campbell, I., Hutchison, D., 1978. A question of priorities: Forbes, Agassiz, and their disputes on glacier observations. Isis 69, 388-399.

Cañón-Tapia, E., Castro, J., 2004. AMS measurements on obsidian from the Inyo Domes, CA: a comparison of magnetic and mineral preferred orientation fabrics. J. Volcanol. Geotherm. Res. 134, 169-182. https://doi.org/10.1016/j.jvolgeores. 2004.01.005.

Cashman, K.V., Soule, S.A., Mackey, B.H., Deligne, N.I., Deardorff, N.D., Dietterich, H.R., 2013. How lava flows: new insights from applications of lidar technologies to lava flow studies. Geosphere 9, 1664-1680. https://doi.org/10.1130/ GES00706.1.

Castro, J., Cashman, K.V., 1999. Constraints on rheology of obsidian lavas based on mesoscopic folds. J. Struct. Geol. 21, 807-819. https://doi.org/10.1016/S01918141(99)00070-X.

Castro, J., Manga, M., Cashman, K., 2002. Dynamics of obsidian flows inferred from microstructures: insights from microlite preferred orientations. Earth Planet. Sci. Lett. 199, 211-226. https://doi.org/10.1016/S0012-821X(02)00559-9.

Christiansen, R.L., Lipman, P.W., 1966. Emplacement and thermal history of a rhyolite lava flow near Fortymile Canyon, Southern Nevada. Geol. Soc. Am. Bull. 77, 671-684.
Cioni, R., Funedda, A., 2005. Structural geology of crystal-rick, silicic lava flows: a case study from San Pietro Island (Sardinia, Italy). In: Manga, M., Ventura, G. (Eds.), Kinematics and Dynamics of Lava Flows. Spec. Pap., Geol. Soc. Am. 396, 1-14. https://doi.org/10.1130/2005.2396(01).

Colgan, W., Rajaram, H., Abdalati, W., McCutchan, C., Mottram, R., Moussavi, M.S., Grigsby, S., 2016. Glacier crevasses: observations, models, and mass balance implications. Rev. Geophys. 54, 119-161. https://doi.org/10.1002/2015RG000504.

Cooper, F.J., Platt, J.P., Behr, W.M., 2017. Rheological transitions in the middle crust: insights from Cordilleran metamorphic core complexes. Solid Earth 8, 199-215. https://doi.org/10.5194/se-8-199-2017.

Cordonnier, B., Schmalholz, S.M., Hess, K.U., Dingwell, D., 2012. Viscous heating in silicate melts: an experimental and numerical comparison. J. Geophys. Res. 117, B02203. https://doi.org/10.1029/2010JB007982.

Deardorff, N., Booth, A., Cashman, K., 2019. Remote characterization of dominant wavelengths from surface folding using lidar and discrete Fourier transform analyses. Geochem. Geophys. Geosyst. 20, 3952-3970. https://doi.org/10.1029/ 2019GC008497.

Fagereng, Å., Biggs, J., 2018. New perspectives on 'geological strain rates' calculated from both naturally deformed and actively deforming rocks. J. Struct. Geol. 125, 100-110. https://doi.org/10.1016/j.jsg.2018.10.004.

Farquharson, J.I., James, M.R., Tuffen, H., 2015. Examining rhyolite lava flow dynamics through photo-based 3D reconstructions of the 2011-2012 lava flowfield at Cordón-Caulle, Chile. J. Volcanol. Geotherm. Res. 304, 336-348.

Farrell, J., Karson, J., Soldati, A., Wysocki, R., 2018. Multiple-generation folding and non-coaxial strain of lava crusts. Bull. Volcanol. 80, 84. https://doi.org/10.1007/ s00445-018-1258-5.

Fink, J.H., 1980a. Surface folding and viscosity of rhyolite flows. Geology 8, 250-254. https://doi.org/10.1130/0091-7613(1980)8<250:SFAVOR>2.0CO;2.

Fink, J.H., 1980b. Gravity instability in the Holocene Big and Little Glass Mountain rhyolitic obsidian flows, Northern California. Tectonophysics 66, 147-166. https://doi.org/10.1016/0040-1951(80)90043-8.

Fink, J.H., 1983. Structure and emplacement of a rhyolitic obsidian flow: little glass mountain, medicine lake highland, northern California. Geol. Soc. Am. Bull. 94, 362-380. https://doi.org/10.1130/0016-7606(1983)94<362:SAEOAR>2.0CO;2.

Fink, J.H., Anderson, S.W., 2017. Emplacement of Holocene silicic lava flows and domes at Newberry, South Sister, and Medicine Lake volcanoes, California and Oregon. U.S. Geol. Surv. Scientific Investigations Report 2017-5022-I. 41 p.

Fink, J.H., Anderson, S.W., Manley, C.R., 1992. Textural constraints on effusive silicic volcanism: beyond the permeable foam model. J. Geophys. Res. 97 (B6), 9073-9083.

Fink, J.H., Bridges, N.T., Grimm, R.E., 1993. Shapes of Venusian “pancake” domes imply episodic emplacement and silicic composition. Geophys. Res. Lett. 20, 261-264. https://doi.org/10.1029/92GL03010.

Fink, J.H., Fletcher, R.C., 1978. Ropy pahoehoe: surface folding of a viscous fluid. J. Volcanol. Geotherm. Res. 4, 151-170. https://doi.org/10.1016/0377-0273(78) 90034-3.

Fink, J.H., Griffiths, R.W., 1992. A laboratory analog study of the surface morphology of lava flows extruded from point and line sources. J. Volcanol. Geotherm. Res. 54, 19-32.

Fink, J.H., Griffiths, R.W., 1998. Morphology, eruption rates, and rheology of lava domes: insights from laboratory models. J. Geophys. Res. 103 (B1), 527-545.

Fink, J.H., Park, S.O., Greeley, R., 1983. Cooling and deformation of sulfur flows. Icarus 56, 38-50.

Gottsmann, J., Dingwell, D.B., 2001. The cooling of frontal flow ramps: a calorimetric study on the Rocche Rosse rhyolite flow, Lipari, Aeolian Islands, Italy. Terra Nova 13, 157-164. https://doi.org/10.1046/j.1365-3121.2001.00332.x.

Grasemann, B., Wiesmayr, G., Draganits, E., Fusseis, F., 2004. Classification of Refold structures. J. Geol. 112, 119-125

Gregg, T.K.P., Fink, J.H., Griffiths, R.W., 1998. Formation of multiple fold generations on lava flow surfaces: influence of strain rate, cooling, and lava composition. J. Volcanol. Geotherm. Res. 80, 281-292. https://doi.org/10.1016/S0377-0273(97) 00048-6.

Hambrey, M.J., Lawson, W., 2000. Structural styles and deformation fields in glaciers: a review. In: Maltman, A.J., Hubbard, B., Hambrey, M.J. (Eds.), Deformation of Glacial Materials. Geol. Soc. (Lond.) Spec. Publ. 176, 59-83.

Harnett, C.E., Kendrick, J.E., Lamur, A., Thomas, M.E., Stinton, A., Wallace, P.A., Utley, J.E.P., Murphy, W., Neuberg, J., Lavallée, Y., 2019. Evolution of mechanical properties of lava dome rocks across the 1995-2010 eruption of Soufrière Hills Volcano, Montserrat. Front. Earth Sci. 7 (7). https://doi.org/10.3389/feart.2019. 00007.

Harris, A.J.L., 2013. Lava flows. Chapter 5. In: Fagents, S.A., Gregg, T.K., Lopes, R.M. (Eds.), Modeling Volcanic Processes: the Physics and Mathematics of Volcanism. Cambridge University Press.

Harris, A.J.L., Flynn, L.P., Matías, O., Rose, W.I., 2002. The thermal stealth flows of Santiaguito dome, Guatemala: implications for the cooling and emplacement of dacitic block-lava flows. Geol. Soc. Am. Bull. 114, 533-546.

Harris, A.J.L., Rowland, S.K., Villeneuve, N., Thordarson, T., 2017. Pāhoehoe, 'a‘ā, and block lava: an illustrated history of the nomenclature. Bull. Volcanol. 79, 7 https://doi.org/10.1007/s00445-016-1075-7. 
Heap, M.J., Violay, M., Wadsworth, F.B., Vasseur, J., 2017. From rock to magma and back again: the evolution of temperature and deformation mechanism in conduit margin zones. Earth Planet. Sci. Lett. 463, 92-100. https://doi.org/10.1016/ j.epsl.2017.01.021.

Hofmeister, A.M., Sehlke, A., Avard, G., Bollasina, A., Robert, G., Whittington, A.G., 2016. Transport properties of glassy and molten lavas as a function of temperature and composition. J. Volcanol. Geotherm. Res. 327, 330-348. https:// doi.org/10.1016/j.jvolgeores.2016.08.015.

Hornby, A.J., Lavallée, Y., Kendrick, J.E., De Angelis, S., Lamur, A., Lamb, O.D., Rietbrock, A., Chigna, G., 2019. Brittle-ductile deformation and tensile rupture of dome lava during inflation at Santiaguito, Guatemala. J. Geophys. Res., Solid Earth 124, 10,107-10,131. https://doi.org/10.1029/2018JB017253.

Houghton, B.F., Wilson, C.J.N., 1989. A vesicularity index for pyroclastic deposits. Bull. Volcanol. 51, 451-462. https://doi.org/10.1007/BF01078811.

Hunt, J.A., Pyle, D.M., Mather, T.A., 2019. The geomorphology, structure, and lava flow dynamics of peralkaline rift volcanoes from high-resolution digital elevation models. Geochem. Geophys. Geosyst. 20, 1508-1538. https://doi.org/10. 1029/2018GC008085.

Ikegami, F., McPhie, J., Carey, R., Mundana, R., Soule, A., Jutzeler, M., 2018. The eruption of submarine rhyolite lavas and domes in the Deep Havre 2012, Kermadec Arc. Front. Earth Sci. 6, 147. https://doi.org/10.3389/feart.2018.00147.

Kääb, A., Weber, M., 2004. Development of transverse ridges on rock glaciers: field measurements and laboratory experiments. In: Premafrost Periglacial Processes, Vol. 15, pp. 379-391.

Leggett, T.N., Befus, K.S., Kenderes, S.M., 2020. Rhyolite lava emplacement dynamics inferred from surface morphology. J. Volcanol. Geotherm. Res. 395.

Lescinsky, D.T., Merle, O., 2005. Extensional and compressional strain in lava flows and the formation of fractures in surface crust. In: Manga, M., Ventura, G. (Eds.), Kinematics and Dynamics of Lava Flows. Spec. Pap., Geol. Soc. Am. 396, 161-177. https://doi.org/10.1130/0-8137-2396-5(2005)396[163:EACSIL]2.0.CO;2.

Lescinsky, D.T., Skoblenik, S.V., Manshina, L., 2007. Automated identification of lava flow structures using local Fourier spectrum of digital elevation data. J. Geophys. Res. 112, B05212. https://doi.org/10.1029/2006JB004263.

Liu, Y., Zhang, Y., Behrens, H., 2005. Solubility of $\mathrm{H}_{2} \mathrm{O}$ in rhyolitic melts at low pressures and a new empirical model for mixed $\mathrm{H}_{2} \mathrm{O}-\mathrm{CO}_{2}$ solubility in rhyolitic melts. J. Volcanol. Geotherm. Res. 143, 219-235. https://doi.org/10.1016/ j.jvolgeores.2004.09.019.

Loney, R.A., 1968. Flow structure and composition of the southern [Coulee, Mono Craters, California] a pumiceous rhyolite flow. Mem. Geol. Soc. Amer. 116.

MacKay, M.E., Rowland, S.K., Mouginis-Mark, P.J., Garbeil, H., 1998. Thick lava flows of Karisimbi Volcano, Rwanda: insights from SIR-C interferometric topography. Bull. Volcanol. 60, 231-259.

Maeno, F., Taniguchi, H., 2006. Silicic lava dome growth in the 1934-1935 Showa Iwo-jima eruption, Kikai caldera, south of Kyushu, Japan. Bull. Volcanol. 68, 673-688. https://doi.org/10.1007/s00445-005-0042-5.

Manga, M., Voltolini, M., Wenk, H.-R., 2018. Microlite orientation in obsidian flow measured by synchrotron X-ray diffraction. Contrib. Mineral. Petrol. 173, 58. https://doi.org/10.1007/s00410-018-1479-9.

Manley, C.R., Fink, J.H., 1987. Internal textures of rhyolite flows as revealed by research drilling. Geology 15, 549-552. https://doi.org/10.1130/0091-7613(1987) $15<549$ :itorfa>2.0.co; 2 .

Maxwell, J.C., 1867. On the dynamical theory of gases. Philos. Trans. R. Soc. 157, 49-88. https://doi.org/10.1098/rstl.1867.0004.

Merle, O., 1998. Internal strain within lava flows from analogue modelling. J. Volcanol. Geotherm. Res. 81, 189-206. https://doi.org/10.1016/S0377-0273(98) 00009-2.

Mukherjee, S., Punekar, J.N., Mahadani, T., Mukherjee, R., 2016. Intrafolial folds: review and examples from the Western Indian Higher Himalaya. In: Mukherjee, S., Mulchrone, K. (Eds.), Ductile Shear Zones: from Micro- to Macro-Scales. Wiley, pp. 287-314

Pal, R., 2003. Rheological behavior of bubble-bearing magmas. Earth Planet. Sci. Lett. 207, 165-179. https://doi.org/10.1016/S0012-821X(02)01104-4.

Pappalardo, R.T., Greeley, R., 1995. A review of the origins of subparallel ridges and troughs: generalized morphological predictions from terrestrial models. J. Geophys. Res. 100 (E9), 18,985-19,007.
Perras, M.A., Diederichs, M.S., 2014. A review of the tensile strength of rock: concepts and testing. Geotech. Geolog. Eng. 32, 525-546.

Plaut, J.J., Anderson, S.W., Crown, D.A., Stofan, E.R., van Zyl, J.J., 2004. The unique radar properties of silicic lava domes. J. Geophys. Res. 109, E03001. https://doi. org/10.1029/2002JE002017.

Pyle, D.M., Elliot, J.R., 2006. Quantitative morphology, recent evolution, and future activity of the Kameni Islands volcano, Santorini, Greece. Geosphere 2, 253-268. https://doi.org/10.1130/GES00028.1.

Quane, S.L., Russell, J.K., 2003. Rock strength as a metric of welding intensity in pyroclastic deposits. Eur. J. Mineral. 15, 855-864. https://doi.org/10.1127/09351221/2003/0015-0855.

Ramsay, J.G., 1967. Folding and Fracturing of Rocks. McGraw-Hill, New York. 568 p.

Ramsey, M.S., Fink, J.H., 1999. Estimating silicic lava vesicularity with thermal remote sensing: a new technique for volcanic mapping and monitoring. Bull. Volcanol. 61, 32-39. https://doi.org/10.1007/s004450050.

Robinson, J.E., Donnelly-Nolan, J.M., Jensen, R.A., 2015. Newberry Volcano's youngest lava flows. In: U.S. Geol. Survey Scientific Investigations Map 3329. 1 sheet.

Romine, W., Whittington, A., Nabelek, P., Hofmeister, A., 2012. Thermal diffusivity of rhyolitic glasses and melts: effects of temperature, crystals and dissolved water. Bull. Volcanol. 74, 2273-2287. https://doi.org/10.1007/s00445-012-0661-6.

Romine, W.L., Whittington, A.G., 2015. A simple model for the viscosity of rhyolites as a function of temperature, pressure and water content. Geochim. Cosmochim. Acta 170, 281-300. https://doi.org/10.1016/j.gca.2015.08.009.

Rust, A.C., Manga, M., Cashman, K.V., 2003. Determining £ow type, shear rate and shear stress in magmas from bubble shapes and orientations. J. Volcanol. Geotherm. Res. 122, 111-132.

Smith, J.V., Houston, E.C., 1994. Folds produced by gravity spreading of a banded rhyolite lava flow. J. Volcanol. Geotherm. Res. 63, 89-94. https://doi.org/10.1016/ 0377-0273(94)90019-1.

Stevens, N.F., 2002. Emplacement of the large andesite lava flow in the Oturere Stream valley, Tongariro Volcano, from airborne interferometric radar. N.Z. J. Geol. Geophys. 45, 387. https://doi.org/10.1080/00288306.2002.9514980.

Stofan, E.R., Anderson, S.W., Crown, D.A., Plaut, J.J., 2000. Emplacement and composition of steep-sided domes on Venus. J. Geophys. Res. 105, 26757-26771. https:// doi.org/10.1029/1999JE001206.

Talbot, C.J., Pohjola, V., 2009. Subaerial salt extrusions in Iran as analogues of ice sheets, streams and glaciers. Earth-Sci. Rev. 97, 155-183.

Tarolli, P., 2014. High-resolution topography for understanding Earth surface processes: opportunities and challenges. Geomorphology 216, 295-312.

Theilig, E., Greeley, R., 1986. Lava flows on Mars: analysis of small surface features and comparisons with terrestrial analogs. J. Geophys. Res. 93 (B13), E93-E126.

Tuffen, H., James, M.R., Castro, J.M., Schipper, C.I., 2013. Exceptional mobility of an advancing rhyolitic obsidian flow at Cordón Caulle volcano in Chile. Nat. Commun. 4, 2709. https://doi.org/10.1038/ncommn3709.

Tuffen, H., McGarvie, D.W., Pinkerton, H., Gilbert, J.S., Brooker, R.A., 2008. An explosive-intrusive subglacial rhyolite eruption at Dalakvísl, Torfajökull, Iceland. Bull. Volcanol. 70, 841-860. https://doi.org/10.1007/s00445-007-0174-X.

Vogel, T.A., Eichelberger, J.C., Younker, L.W., Schuraytz, B.C., Horkowitz, J.P., Stockman, H.W., Westrich, H.R., 1989. Petrology and emplacement dynamics of intrusive and extrusive rhyolites of Obsidian Dome, Inyo Craters Volcanic Chain, Eastern California. J. Geophys. Res. 94, 17937-17956. https://doi.org/10.1029/ JB094iB12p17937.

Warner, N.H., Gregg, T.K.P., 2003. Evolved lavas on Mars? Observations from southwest Arsia Mons and Sabancaya volcano, Peru. J. Geophys. Res. 108 (E10), 5112. https://doi.org/10.1029/2002JE001969.

Webb, S.L., Dingwell, D.B., 1990. Non-Newtonian rheology of igneous melts at high stresses and strain rates: experimental results for rhyolite, andesite, basalt, and nephelinite. J. Geophys. Res., Solid Earth 95, 15695-15701. https://doi.org/10. 1029/JB095iB10p15695.

Whitehead, P.W., Stephenson, P.J., 1998. Lava rise ridges of the Toomba basalt flow, north Queensland, Australia. J. Geophys. Res. 103 (B11), 27,371-27,382.

Whittington, A., Richet, P., Polian, A., 2012. Water and the compressibility of silicate glasses: a Brillouin spectroscopic study. Am. Mineral. 97, 455-467. 